OECD Economics Department Working Papers No. 394

\title{
Pietro Catte,
}

Housing Markets, Wealth

Nathalie Girouard, and the Business Cycle

\section{Christophe André}


Organisation de Coopération et de Développement Economiques

Organisation for Economic Co-operation and Development

22-Jun-2004

ECONOMICS DEPARTMENT

English - Or. English

HOUSING MARKETS, WEALTH AND THE BUSINESS CYCLE

ECONOMICS DEPARTMENT WORKING PAPERS NO. 394

By Pietro Catte, Nathalie Girouard, Robert Price and Christophe André

All Economics Department Working Papers are now available throught OECD's Internet Web site at http://www.oecd.org/eco/ 


\section{TABLE OF CONTENTS}

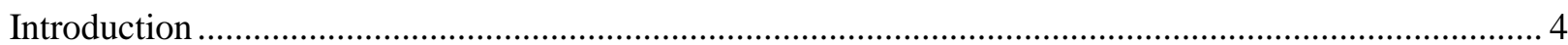

House prices, housing wealth and the cycle in OECD countries: some stylised facts ........................... 6

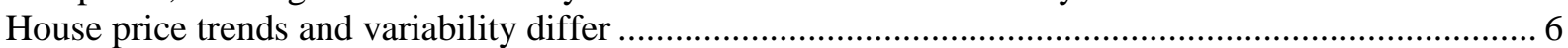

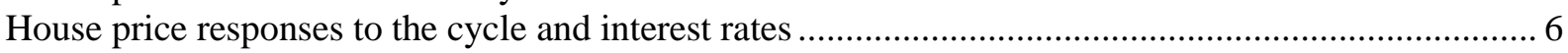

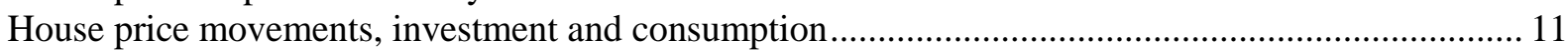

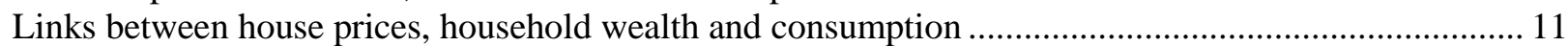

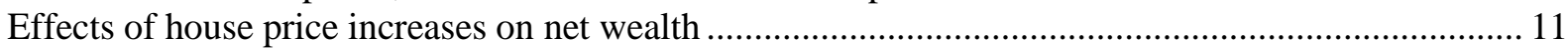

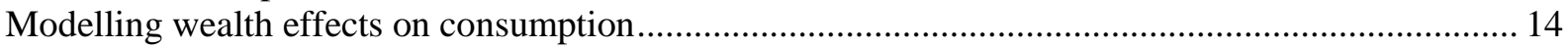

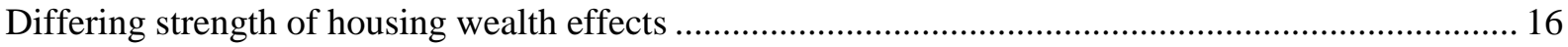

The role of mortgage debt and housing equity withdrawal .............................................................. 17

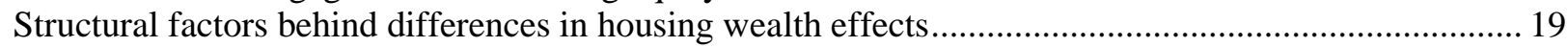

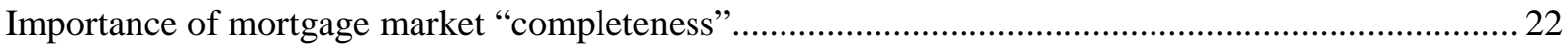

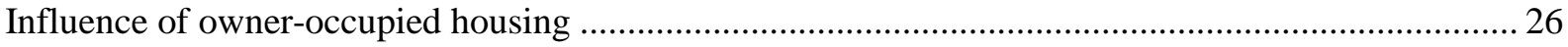

Housing transaction costs and the taxation of housing capital gains.................................................. 26

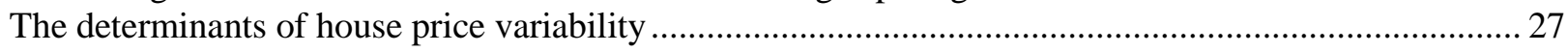

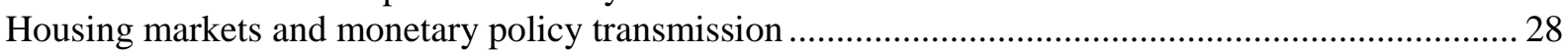

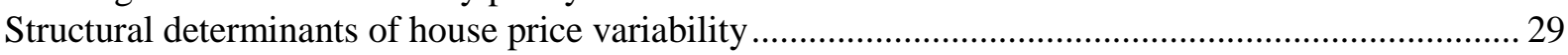

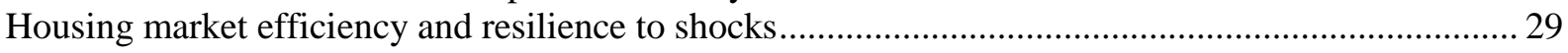

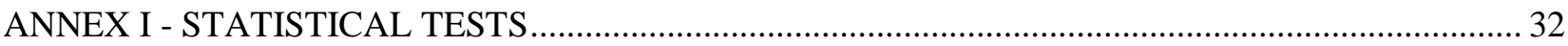

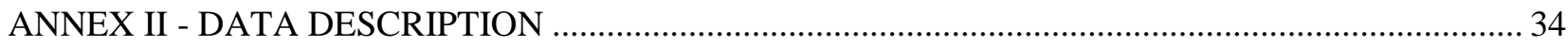

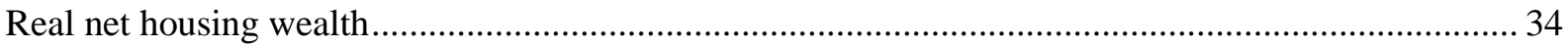

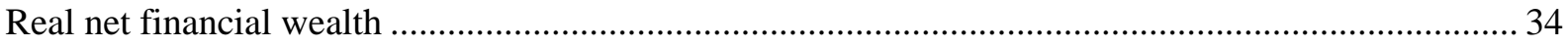

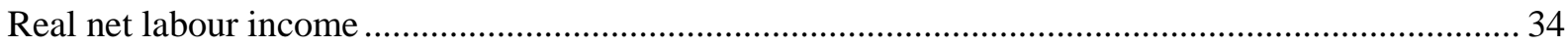

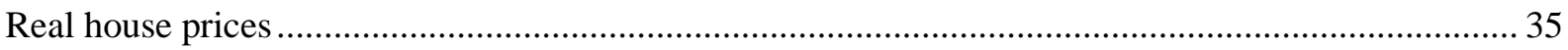

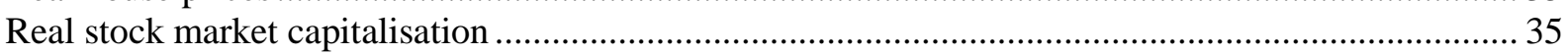

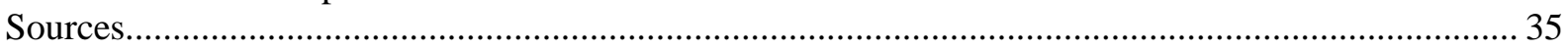

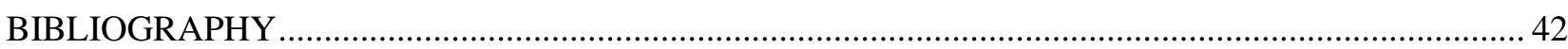




\section{ABSTRACT/RÉSUMÉ \\ Housing markets, wealth and the business cycle}

The paper examines the linkages between housing markets and the business cycle in OECD countries, focusing on how differences in the degree of resilience to economic shocks can be affected by the structural characteristics of housing and mortgage markets. The paper focuses specifically on: the transmission channel from housing wealth to consumption and on the factors behind house price variability, which help to determine whether the housing sector plays a stabilising role or not. Estimates of the marginal propensity to consume out of housing wealth are presented for ten OECD countries, where it is found that the strongest impact on consumption is in countries that have large, efficient and responsive mortgage markets. Particularly important in this regard is the degree of mortgage market "completeness" -- i.e. the extent to which the market is able to offer a variety of products and to serve a broad range of potential borrowers -- in particular, the extent to which they provide opportunities for housing equity withdrawal. With regard to house price variability, the significant differences found among OECD countries appear to be connected both to macro-economic factors (such as inflation variability) and to structural ones. House prices seem to be subject to larger oscillations in countries where housing supply is relatively inelastic (due, for example, to unnecessarily restrictive zoning regulations) and where a favourable tax treatment of mortgage interest encourages the leveraging of housing equity. A tentative conclusion is that structural policy settings that are desirable for the sake of efficient resource allocation also tend to be conducive to greater macro-economic resilience to shocks.

JEL classification: D12, E21, E32

Keywords: Consumption, wealth, house prices, mortgage markets, business cycles

*******

Cette étude examine les liens entre les marchés immobiliers et le cycle économique dans les pays de l'OCDE, se concentrant sur le rôle des spécificités nationales des marchés immobiliers et hypothécaires sur l'inégale résilience face aux chocs économiques. Cette étude s'intéresse particulièrement au canal de transmission de la richesse immobilière à la consommation et aux facteurs expliquant la variabilité des prix des logements ; ces deux aspects contribuent à déterminer si le secteur immobilier joue un rôle stabilisateur ou non. Des estimations de la propension marginale à consommer la richesse immobilière sont présentées pour dix pays de l'OCDE. Ces estimations indiquent que les effets les plus important sur la consommation apparaissent dans les pays ayant des marchés hypothécaires de grande taille, efficients et réactifs. Le niveau de «complétude » du marché hypothécaire -- la mesure dans laquelle le marché peut offrir une variété de produits et répondre à un large éventail d'emprunteur potentiel -- est particulièrement important à cet égard, ainsi que la possibilité d'offrir des prélèvements adossés à un actif immobilier. S'agissant de la variabilité des prix des logements, les principales différences rencontrées dans les pays de l'OCDE semblent reliées à la fois aux facteurs macroéconomiques (tel que la variabilité de l'inflation) et aux facteurs structurels. Les prix de l'immobilier seraient soumis à des fluctuations erratiques dans le cas d'une offre de logements relativement inélastique face aux variations de prix (reflétant par exemple, des réglementations de zonage inutilement restrictives) et dans le cas d'incitations fiscales trop avantageuses encourageant les prélèvements adossés à un actif immobilier. En guise de conclusion, il semble que les politiques structurelles qui sont souhaitable afin d'obtenir une allocation efficace des ressources seraient aussi conductrice d'une plus grande résilience aux chocs.

Classification JEL : D12, E21, E32

Kmots-clés : Consommation, richesse, prix des logements, marchés hypothècaires, cycles économiques 


\section{HOUSING MARKETS, WEALTH AND THE BUSINESS CYCLE ${ }^{1}$ Pietro Catte, Nathalie Girouard, Robert Price and Christophe André}

\section{Introduction}

1. OECD economies have exhibited different degrees of resilience over the recent cyclical downturn, in the sense that some were better than others at weathering and recovering from a set of common shocks. In some measure, differences in resilience seem to be related to the performance of housing markets. In particular, house price buoyancy in some countries appears to have boosted private consumption and residential construction and thereby helped to offset weaknesses elsewhere. It appears that institutional set-ups in housing and mortgage markets play an important role not just for overall economic efficiency and real incomes but also for the propagation of shocks. Hence, structures which enhance longer-term economic performance may also lead to better short-term outcomes. Moreover, while structural reforms should be undertaken primarily for longer-term efficiency reasons, they may also have important implications for macroeconomic policy effectiveness. Thus, housing market institutions seem to influence the speed and magnitude with which monetary policy responses to shocks are transmitted through economies. This paper aims to shed light on some of these linkages. ${ }^{2}$

2. The paper starts with an examination of stylised facts, addressing questions such as: how closely associated are house prices and output over the cycle? What role do mortgage debt and housing wealth play in linking house prices to demand and activity? How do countries differ in this regard? It then investigates how institutions affect the cyclical behaviour of house prices, and thus household demand, in individual countries. In this process special attention is paid to the characteristics of the mortgage market which may facilitate or impede the influence of housing wealth on household expenditure. The analysis thus focuses on an important aspect of the transmission mechanism of monetary policy and the overall responsiveness of the housing market to shocks. The paper concludes with an investigation of some of the macroeconomic and structural policy factors behind house-price variability which may sometimes lead to speculative housing market bubbles, with the aim of identifying the conditions in which the benefits of housing market flexibility for macroeconomic resilience and stability are best achieved.

3. The structure of the paper is as follows. The following section presents a number of stylised facts regarding the main interactions between housing markets and the business cycle and the subsequent section focuses specifically on the impact of changes in housing wealth on consumption, presenting econometric estimates for a number of OECD countries and identifying some key cross-country

1. Robert Price, Nathalie Girouard and Christophe André are members of the General Economic Analysis Division and Pietro Catte is a member of the Money and Finance Division of the OECD Economics Department. They are grateful to Jean-Philippe Cotis, Michael Feiner, Jorgen Elmeskov, Peter Jarret, Sveinbjorn Blöndal and Paul van den Noord for the helpful comments and suggestions. They would like to thank Isabelle Wanner and Catherine Lemoine for technical assistance and Anne Eggimann and Sarah Kennedy for secretarial assistance.

2. Housing markets can also have important implications for economic resilience via their effect on labour mobility. However, these aspects are not examined in this paper. 
differences. An attempt is then made to connect these differences with a variety of institutional and regulatory characteristics of national housing and mortgage markets. In the final section the analysis is extended to a discussion of the determinants of cross-country differences with regard to, respectively, the impact of interest rates on house prices and the structural factors which affect house price variability, both of which help to determine the extent to which the housing sector adds to economic resilience. The paper ends with a brief discussion of the institutional characteristics of mortgage and housing markets that are most desirable for the sake of economic efficiency and macroeconomic resilience.

4. The main conclusions from this work are:

- Real house price movements, which have often differed markedly across countries, tend to lag cyclical peaks and troughs -- but in ways that differ not only across countries but also from one cycle to another. ${ }^{3}$

- Feed-through from house prices to activity occurs largely through wealth channels affecting personal consumption. This may reflect in part a traditional wealth effect as envisaged in lifecycle models, but probably also an impact via higher collateral values facilitating households' access to mortgage financing.

- The behaviour of residential construction over the business cycle also shows important differences, with the volume response at turning points both stronger and more rapid in some countries than in others.

5. Differences in institutional features of housing and mortgage markets significantly influence the interaction between housing and the business cycle:

- Certain mortgage market characteristics, and in particular their degree of "completeness", strengthen the wealth effect on consumption. Lower transaction costs and higher owneroccupation rates may also assist this transmission process.

- The effects of monetary policy on activity, as measured by the impact of policy-determined interest rate changes on housing market interest rates and then to house prices and wealth, differ considerably among OECD economies This may also be related to institutional factors, such as the type of mortgage interest regime that predominates (particularly floating or fixed rate), the costs of refinancing and the extent to which the mortgage market is flexible in its response to changes in housing demand.

- While economic resilience may be enhanced by removing mortgage market rigidities and facilitating a stronger monetary policy response via housing wealth channels, partial and/or ill-timed reforms can cause imbalances to emerge, in the form of housing price bubbles. More generally, resilience is strengthened and potential instability reduced to the extent that distortions are avoided (such as, for example, a non-neutral housing tax structure or unnecessarily restrictive zoning regulations), that monetary policy is effective in controlling inflation, and that prudential controls are in place to ensure the solidity of financial institutions faced with variations in house prices.

3. Throughout this paper, references to real house prices indicate nominal house prices deflated using the private consumption deflator. 


\section{House prices, housing wealth and the cycle in OECD countries: some stylised facts}

\section{House price trends and variability differ}

6. Based on an analysis of the behaviour of real house prices since 1970 in a group of 18 OECD countries $^{4}$ and of their correlations with key macroeconomic variables such as the output gap, private consumption, residential investment, a number of stylised facts can be identified, consistent with the empirical literature on the subject.

7. Since the mid-1990s residential property prices have recorded widely differing rates of increase in real terms among OECD countries (Figure 1, panel A). In general, most of the countries that have registered the most significant recent run-up in real house prices have also shown a marked longer-term rising trend. Germany, Japan and Switzerland stand out as countries where real house prices have shown a decline since the mid-1990s, and their level is now not far from where it was in 1970. Neither the crosscountry differences in long-term price trends nor the recent acceleration in some countries can be attributed to demographic factors. In most countries covered in Figure 1, average population growth since 1990 has been little different or slower than in the previous ten years, the main exception being Ireland. Moreover, in virtually all of them there was a strong deceleration in the growth of the population in the 25-34 year age group, the one more likely to form new families and add to demand for housing, even though the effect of this on housing demand was probably offset by the decline in average family size. ${ }^{5}$

8. Differences in average rates of real house price growth have been accompanied by marked differences in their variability (Figure 1, panel B). The standard deviation of real house price changes over the whole 1970-2002 period is particularly high in some of the countries that have experienced the largest trend price increases (the Netherlands, Spain and the United Kingdom), suggesting that secular and cyclical movements may have a common root. By contrast, price variability is much lower in Germany and the United States, where, however, regional house prices tend to show greater variation than the country average.

\section{House price responses to the cycle and interest rates}

9. In all countries, residential property markets tend to track the business cycle, with a tendency for real house price turning points to lag business cycle peaks and troughs (Figure 2). On many occasions in the past, house prices continued to decline in real terms for a few years after output had picked up. Conversely, prices often continued rising during the early part of a cyclical downturn. However, the lags between house prices and the business cycle have differed across countries (Table 1). Moreover, they have differed from cycle to cycle. During the recent downturn, in several countries - notably the United States, the United Kingdom, Australia, Ireland and Spain - house prices not only continued to rise, but actually accelerated after the output turning point. ${ }^{6}$

4. The 18 OECD countries are those included in the Bank for International Settlements' residential property price database (see Figure 1). For New Zealand, however, data from Quotable Value New Zealand have been used.

5. The only countries where house price movements appear to be strongly correlated with population growth are Luxembourg and New Zealand, mainly reflecting changes in net migration. Across countries, however, no correlation seems to exist between the size of the house price acceleration and the change in population growth rates between the 1980 s and the 1990 s.

6. See OECD Economic Outlook, No. 74, page 20. 
Figure 1. Real house prices : average annual increase and variability

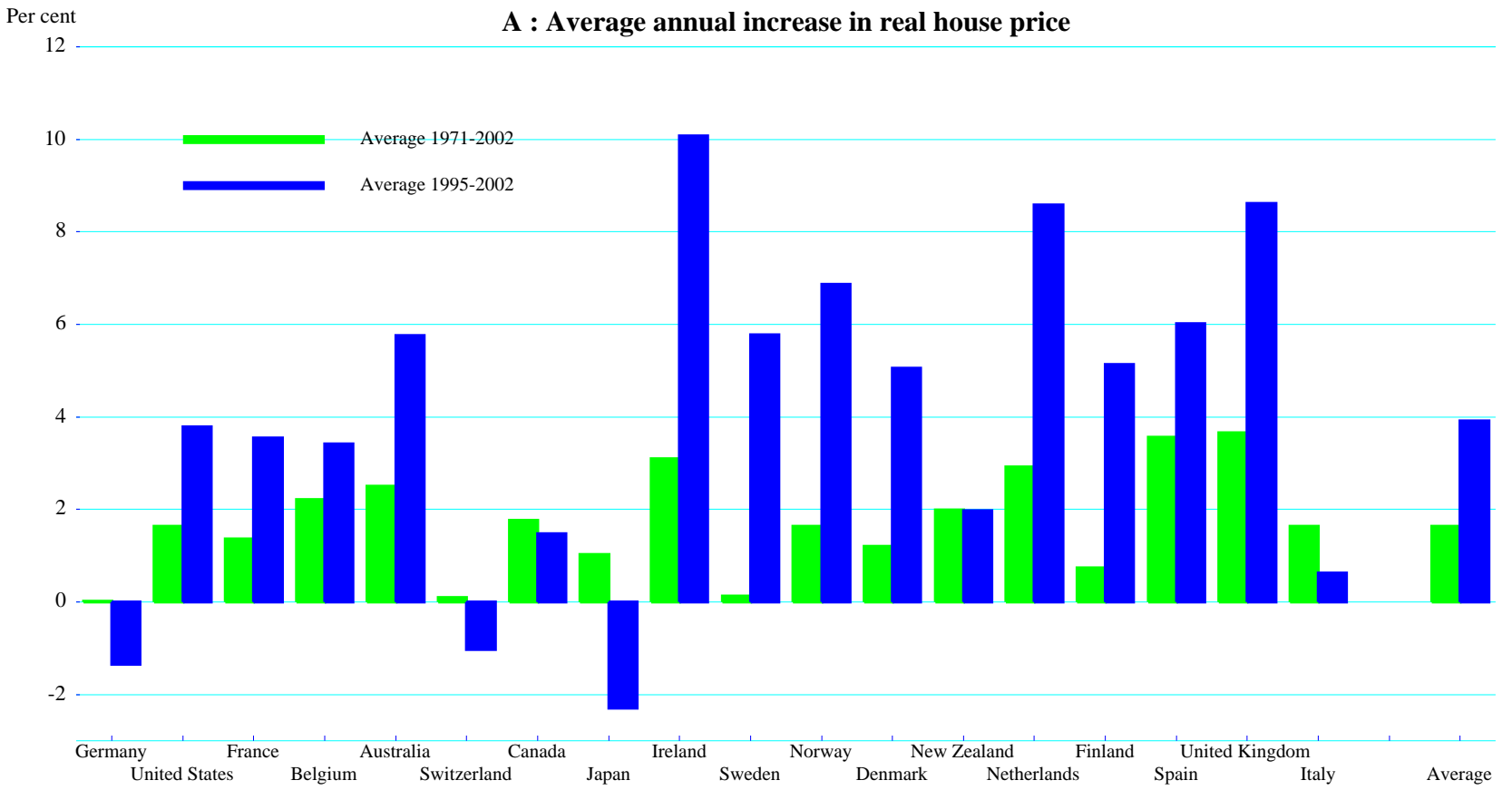

Per cent $\quad$ B : Standard deviation of annual percentage changes (1971-2002)

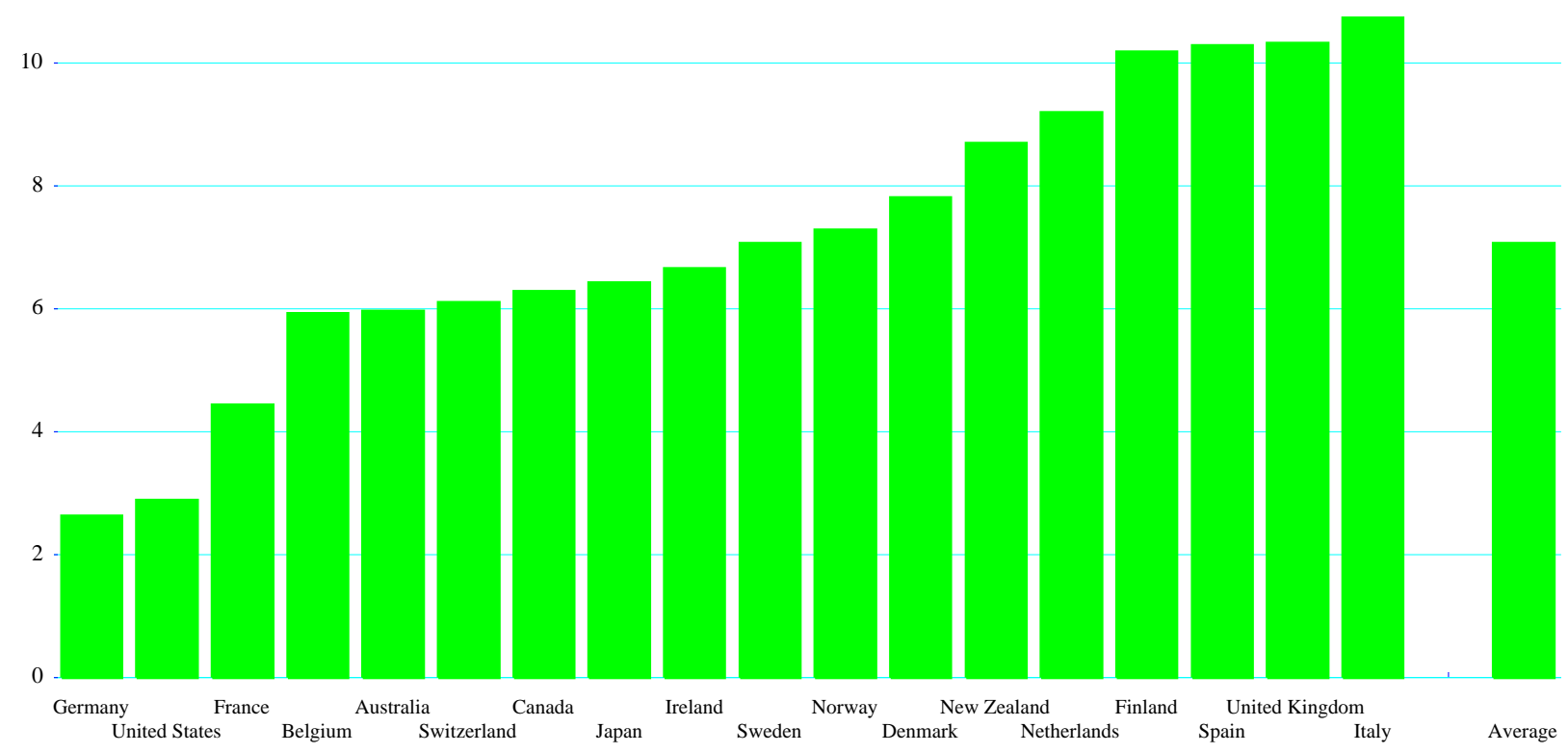

Note : House prices are deflated using the private consumption deflator. Source : Bank for International Settlements, Quotable Value New Zealand. 
Figure 2. Real house prices and the output gap
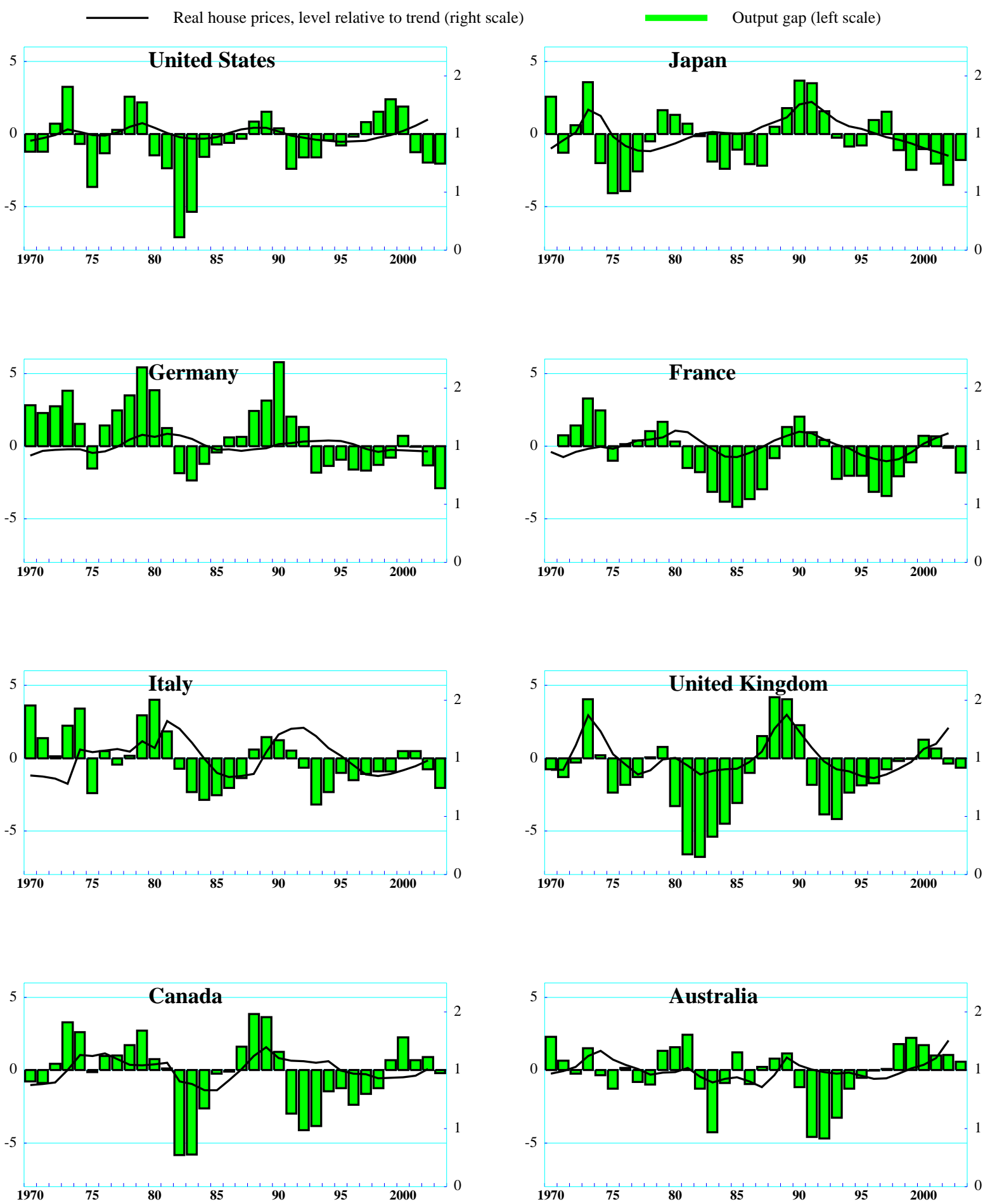

Sources : Bank for International Settlements, Quotable Value New Zealand and OECD. 
Figure 2 (cont.) Real house prices and the output gap
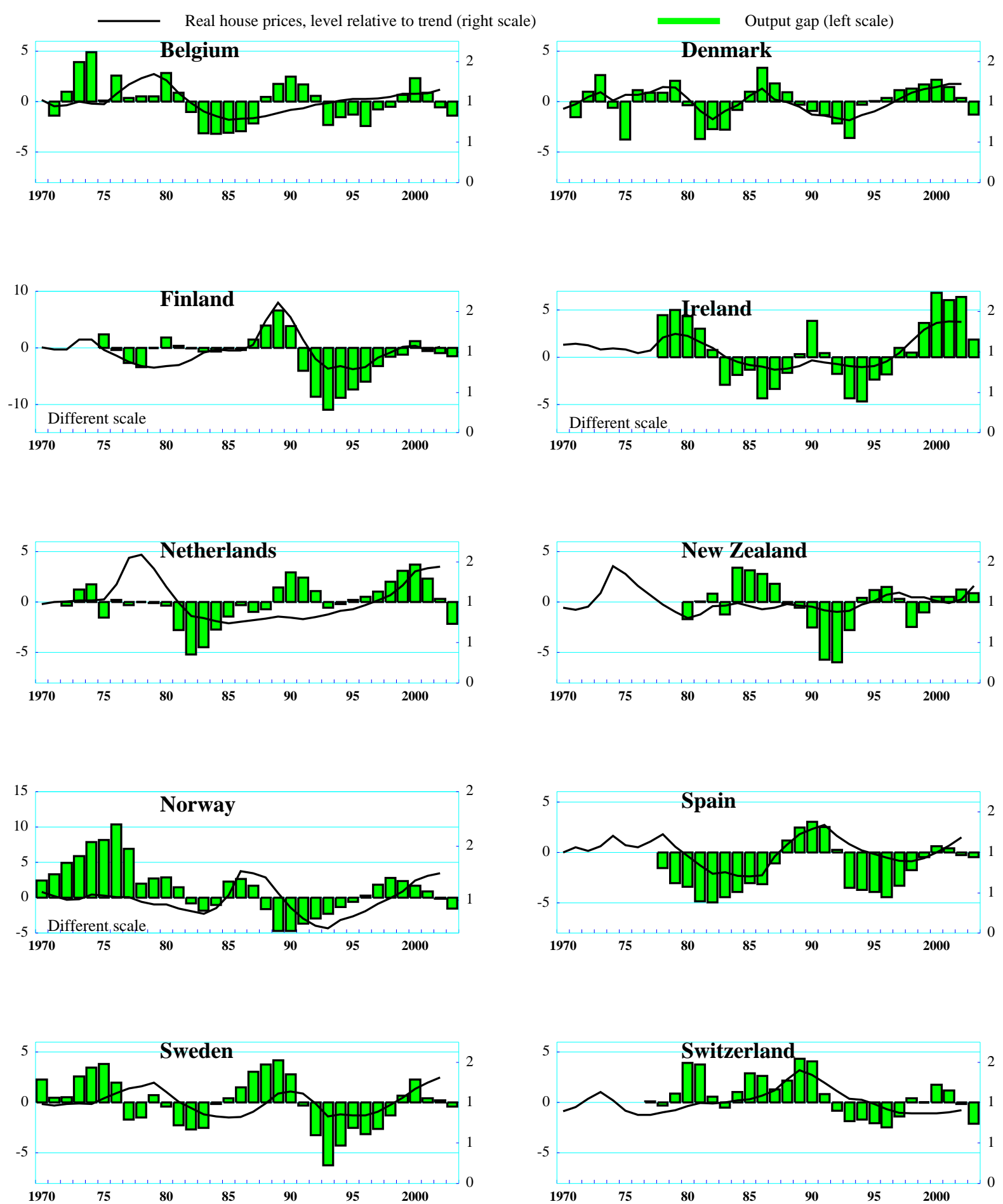

Sources : Bank for International Settlements, Quotable Value New Zealand and OECD. 


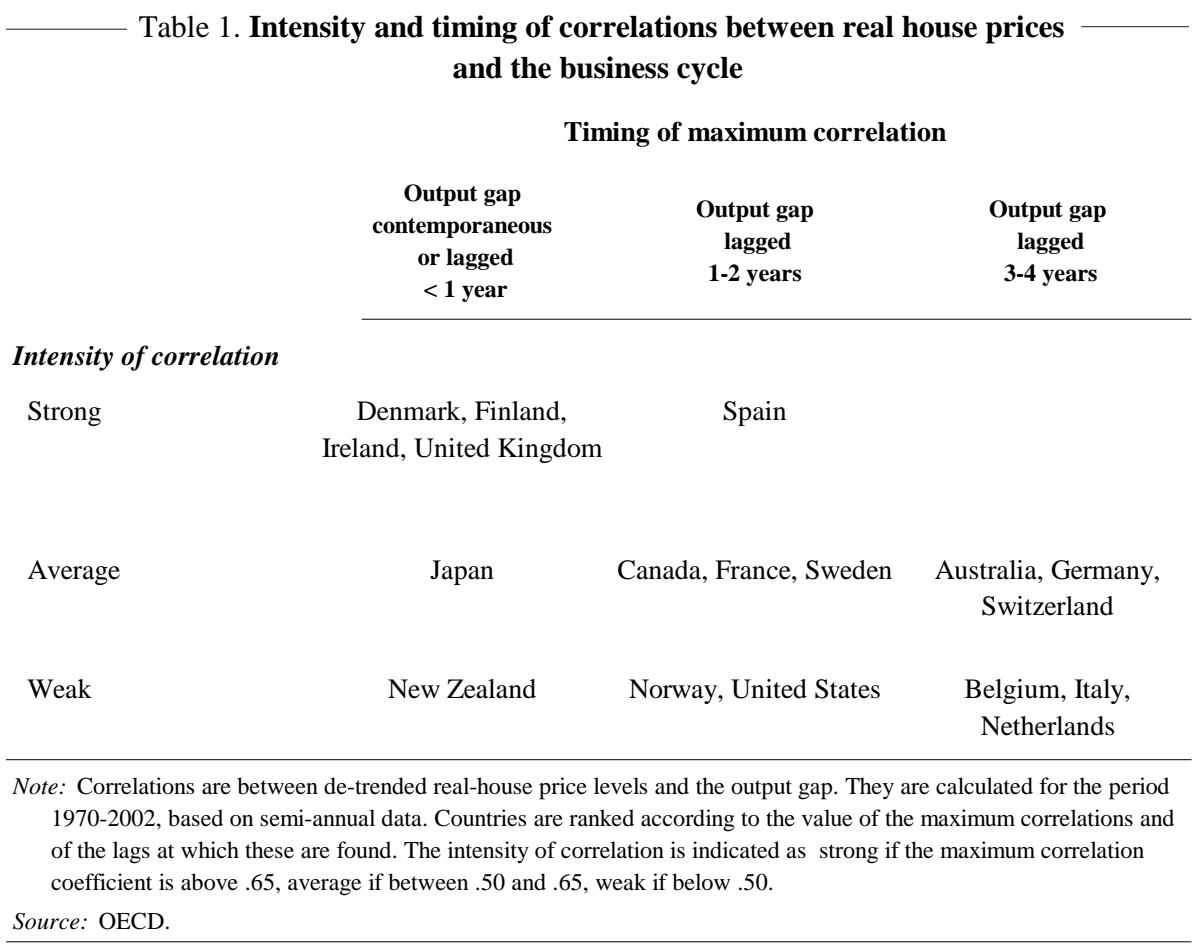

10. Other evidence suggests that prices in residential property markets adjust to cyclical conditions more gradually than equity markets. ${ }^{7}$ While not all equity price peaks are followed by one in house prices, the occurrence of an equity market boom significantly increases the probability that a house price surge will occur and that, in general, house price peaks tend to follow major equity market peaks by at least one year, and on average two years. Also, the cumulative house price decline following a peak is usually larger the greater has been the preceding rise and the more significant the financial imbalances which have accumulated during the boom.

11. The empirical literature also finds that house prices -- and hence the correlations between house prices and output -- are affected by interest rate changes, the behaviour of which has varied across cycles. ${ }^{8}$ House price downturns in response to output cycles tend to be delayed and the subsequent price decline to be smaller when interest rates rise less than usual or decline after an equity market peak. ${ }^{9}$ This is consistent with the findings of the more general literature on the transmission of monetary policy. However, the statistical relationship between interest rates and house price movements differs widely in speed and strength across countries.

7. See Borio and McGuire (2004) who analyse equity and house price cycles in a group of OECD countries over the past 30 years.

8. In the study referred to above, Borio and McGuire (2004) find that interest rate movements can affect the relationship between house prices and the business cycle..

9. See for example Sutton (2002) and Tsatsaronis and Zhu (2004). 


\section{House price movements, investment and consumption}

12. The lagged relationship between the cycle and house prices is reflected in the fact that the volume of residential investment has widely tended to turn around rather earlier than house prices in cyclical upswings and downturns, the major euro-area economies and the Netherlands being the main exceptions to this pattern. At least in the United States and the United Kingdom, residential investment seems to lead output. ${ }^{10}$ Since, on the other hand, house prices tend to lag output in virtually all countries, as mentioned above, this suggests that residential investment cycles are not driven principally by house prices, as a simple Tobin-q investment model would predict. Empirical research suggests that interest rates affect housing investment directly. ${ }^{11}$ Perhaps related to this, the amplitude of housing investment cycles has declined significantly since the mid-1980s in the United States, although not -- or not to the same extent -in most other countries. ${ }^{12}$ Indeed, the recent downturn seems to have been unusual in that, again with the exception of continental European countries, housing investment as well as house prices remained buoyant through the brief cyclical downswing and into the following recovery (Figure 3).

13. The channel by which house prices affect the shape of the cycle would seem to run primarily via changes in the value of the household sector's housing wealth, which help determine consumer behaviour and hence movements in household saving ratios. Changes in house prices are correlated with private consumption in most countries -- on average for all countries over the entire period the correlation of annual consumption growth with simultaneous changes in real house prices is 0.58 -- but to widely varying degrees (Figure 4).

\section{Links between house prices, household wealth and consumption}

14. To assess the strength of the link between house prices and consumption, this section presents estimates of the marginal propensity to consume out of housing wealth for a number of OECD countries. The results seem to confirm the existence of significant housing wealth effects on consumption in the United States, United Kingdom, Canada, the Netherlands and Australia. By contrast, in France, Germany and Italy the consumption response to changes in wealth remains limited.

\section{Effects of house price increases on net wealth}

15. The approach used here separates housing wealth from financial wealth as determinants of consumption. A preliminary issue to be addressed, however, is whether house price increases do in fact add to the household sector's net wealth. Because households both own housing assets and consume the housing services deriving from them, capital gain to the owner is partly or fully offset by the higher

10. See Aoki et al. (2002).

11 McCarthy-Peach (2002).

12. As an explanation for the lower variability of housing investment, McCarthy and Peach (2002) cite the regulatory changes in US mortgage markets, which have reduced the extent of credit rationing. Stock and Watson (2002) also mention the lower variability of real interest rates. 
Figure 3. The cyclical behaviour of housing investment index, cyclical trough $=100$
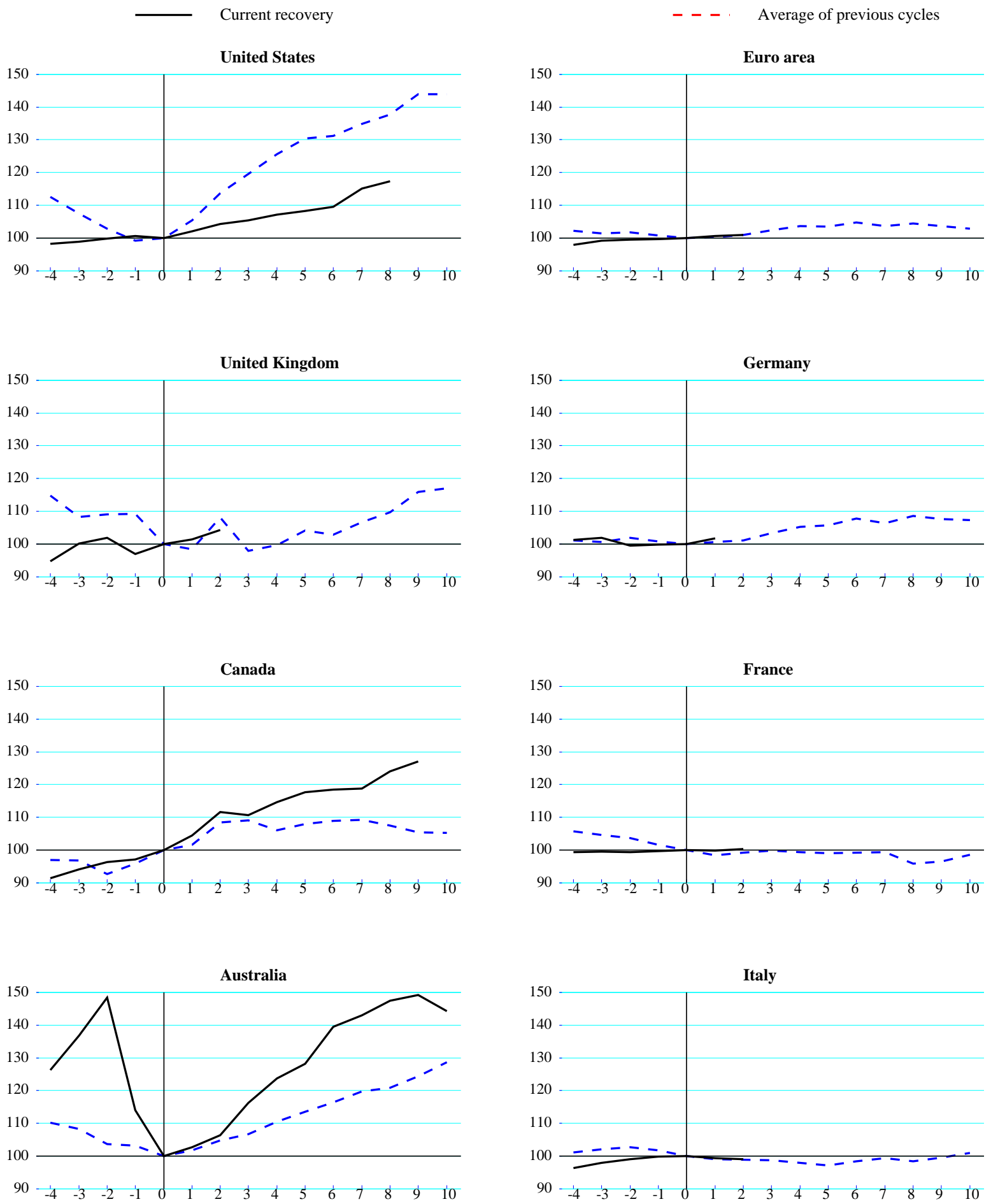

Note: The last cyclical trough is 2000Q4 for Australia, 2001Q3 for Canada, 2001Q4 for the United States and 2003 Q2 for the European countries. Source: OECD. 
Figure 4. Correlation of private consumption growth with real house price changes

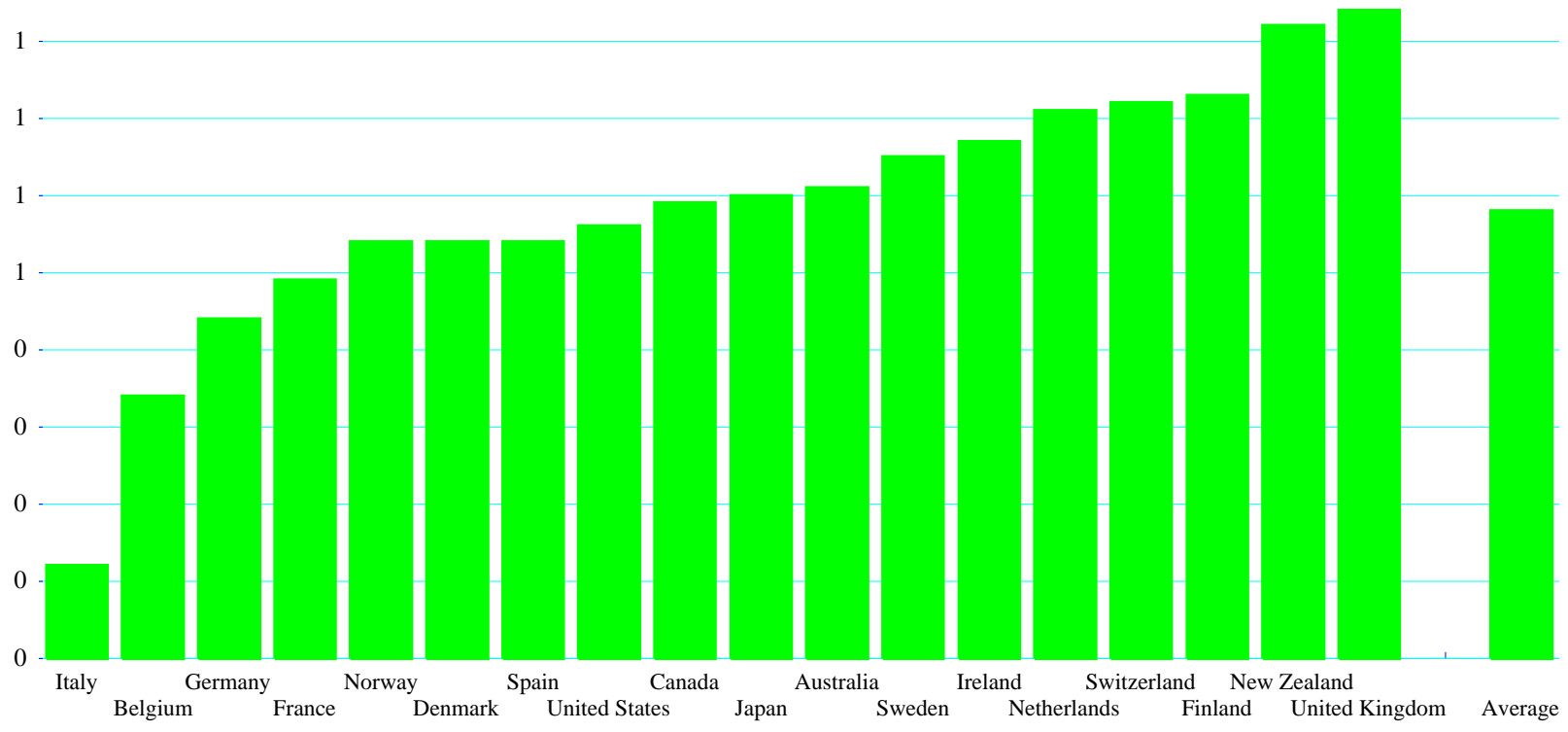

Notes: Contemporaneous correlation coefficients are calculated from annual data, 1971 to 2002 . Source : Bank for International Settlements, Quotable Value New Zealand and OECD.

discounted value of future imputed rents when house prices rise. ${ }^{13}$ Unlike a rise in equity prices, which can reflect an increase in the economy's expected productive potential, and thus of future income, higher house prices may simply reflect increased scarcity owing to higher demand, with no net change in either the quantity or the quality of the services they can provide. In that case, there would be no change in national wealth. Nevertheless, even if aggregate wealth is unchanged, house price increases usually affect the relative positions of specific groups of people - for example, of current home-owners vis-à-vis would-be home buyers. These wealth transfers can have macro-economic effects if these categories' propensities to spend differ, as they would be expected to. Furthermore, a change in the relative price of housing can induce consumers to substitute towards non-housing expenditure.

16. These considerations suggest that there are valid theoretical reasons to consider housing assets separately from other financial or productive assets. In particular, the marginal propensities to consume out of financial and housing wealth could differ due to a number of factors, which however can work in opposite directions.

13. The extent of the offset depends on the owners' effective time horizon, that is, on whether they intend to sell their housing assets during their lifetime or to pass it on to their offspring. If current wealth holders fully internalize the welfare of future generations, so that their economic planning horizon is effectively infinite, the expected cost of future imputed rents fully offsets the value of housing assets (a conclusion that has some analogy with the Ricardian equivalence proposition on the effects of government debt). 
- As already mentioned, the effect of higher house prices on wealth is partly or fully offset by the higher cost of present and future housing services consumed, unlike for financial assets. To the extent that most variations in housing wealth reflect valuation changes rather than changes in the housing stock, the propensity to consume out of housing wealth should be lower. The net effect will depend, inter alia, on the share of owner-occupied housing, on the extent to which actual rents in the rental sector move in line with house prices, and on the existence of behavioural asymmetries among the various categories.

- On the other hand, housing wealth can facilitate access to credit for liquidity-constrained households, which may not have access to uncollateralized consumer credit or may find it prohibitively expensive. Housing assets constitute the most important form of collateral available to them, also because they are less concentrated among certain segments of the population than financial assets. And households with lower overall wealth are more likely to be liquidityconstrained than wealthier households. Because of such distributional effects, a change in aggregate housing wealth may have a stronger effect on consumption than an equivalent change in financial wealth, if mortgage markets allow homeowners to borrow easily against housing equity. ${ }^{14}$

- House prices may be perceived as being less volatile than the prices of certain financial assets, particularly equities. Therefore, households might be willing to modify their consumption more rapidly following a change in house prices. ${ }^{15}$

- The cost of realising capital gains on housing is potentially important, since one way in which households can obtain liquidity out of higher house prices is by trading down to less expensive housing. On the one hand, transaction costs are much higher on housing assets than on financial assets; on the other hand, in a number of countries capital gains on housing (especially if owneroccupied) are exempt from taxation.

- Finally, some of the factors mentioned above may interact with the age structure of the population. For example, as the share of home equity in household net wealth tends to increase with age, this may help offset the fact that older households have a large fraction of their wealth in illiquid form (e.g. life insurance and pension funds). ${ }^{16}$

17. In summary, whether the marginal propensity to consume out of housing wealth should be higher or lower than that out of financial wealth is ambiguous on theoretical grounds. The net effect of the above mentioned factors needs to be assessed empirically. Moreover, all these factors can differ considerably across countries according to institutional features and the economic and financial structure.

\section{Modelling wealth effects on consumption}

18. The approach used in this study is based on the life cycle hypothesis, with consumption depending on households' lifetime income and wealth. In the long run, trends in consumption are closely related to trends in income and wealth. Consumption deviates from this long run equilibrium in the short term but will tend to gradually revert to equilibrium over time. This process is modelled as an error

14. See Di (2003), Drolet et al. (2002), Boone et al. (2002), Bundesbank (2003) and Flandrin (2004).

15. See Lettau and Ludvigson (2003).

16. See Venti and Wise (2001) and Mitchell and Piggott (2004). 
correction mechanism. The short run dynamic terms which can lead to deviations from the trends can include lagged values of income and wealth, along with other factors such as interest rates, unemployment and inflation as in the long term equation.

19. The specification used incorporates disaggregated wealth components as different categories of wealth may affect consumption with different magnitude as discussed above. The consumption equation can be written more formally as:

$$
c=\alpha+\beta(y)+\omega(n f w r)+\gamma(n h w r)+\delta(u n r)+\phi(i r s r)+\theta(\mathrm{inf})+e c t
$$

where $c$ is real consumption, $y$ is real labour income excluding property income to avoid the risk of double counting return earned on financial assets, $n f w r$ represents real net financial wealth defined as financial assets minus financial liabilities other than mortgages, $n h w r$ is real net housing wealth defined as housing assets minus households mortgages ${ }^{17}, u n r$ is the unemployment rate, irsr is the real short term interest rate and inf is the inflation rate. For Italy and Germany, proxies for wealth data (real stock market capitalisation and real house prices) were used due to limited wealth data availability. All variables are expressed in logarithmic form. $\alpha$ is a constant and $\beta, \omega$ and $\gamma$ are long term elasticities with respect to income, financial wealth and housing wealth respectively. ect is the residual from the regression. The regressions are estimated using the Stock and Watson procedure. ${ }^{18}$ The estimated short run relationship is as follow:

$$
\begin{aligned}
& \Delta(c)=\tau e c t(-1)+\sum_{i=1}^{n} \gamma_{i} \Delta(c)(-i)+\sum_{i=1}^{n} \nu_{i} \Delta(y)(-i)+\sum_{i=0}^{n} \lambda_{i} \Delta(n f w r)(-i)+\sum_{i=0}^{n} \lambda_{i} \Delta(n h w r)(-i) \\
& +\sum_{i=0}^{n} \kappa_{i} \Delta(\text { unr })(-i)+\sum_{i=0}^{n} \rho_{i} \Delta(i r s r)(-i)+\sum_{i=0}^{n} v_{i} \Delta(\text { inf })(-i)
\end{aligned}
$$

where $\Delta$ represents first-order differences and $e c t(-1)$ is the error-correction term from the cointegrating vector. This equation is estimated with OLS.

20. The results presented below appear to be robust to a number of possible changes in specification that were tried. In particular, the main results would not be substantially different if the housing wealth variable were defined in gross terms (i.e. without netting out residential mortgage debt) - in which case mortgage debt is subtracted from net financial assets - or if variables were expressed in actual levels rather than in logarithms. The specification in actual levels has the advantage that the estimated coefficients for $y$, $n f w r$ and $n h w r$ can be directly interpreted as marginal propensities to consume. By contrast, if these variables are expressed in logarithms the coefficients are elasticities, which need to divided by the ratio of the respective variable to consumption to recover the corresponding marginal propensity to consume. ${ }^{19}$ The specification presented above was retained because it provides the best econometric fit.

17. In Spain, gross housing wealth series was used due to a short sample of data for mortgage debt.

18. Stock and Watson (1993) suggest including leads and lags to address the endogeneity bias in OLS estimates of cointegrating relationships.

19. To calculate the marginal propensities to consume presented in the text, the average values of these ratios over the sample period were used. 


\section{Differing strength of housing wealth effects}

21. The results based on the life-cycle model suggest that a wealth channel operates in all countries, with magnitudes similar to those found in previous research. ${ }^{20}$ The long-run marginal propensities to consume out of financial wealth are between 0.01 and 0.02 for France, Germany, Italy and Spain and vary between 0.03 and 0.07 for Australia, Canada, Japan, the Netherlands, the United Kingdom and the United States (Table 2) ${ }^{21}$. The estimated long run marginal propensity to consume out of housing wealth is in the range of between 0.05 and 0.08 for Australia, Canada, the Netherlands, the United Kingdom and the United States while it is between 0.01 and 0.02 in Italy, Japan, and Spain and statistically insignificant in France and Germany. In the former five countries, the housing wealth effect appears to be larger than the financial wealth effect.

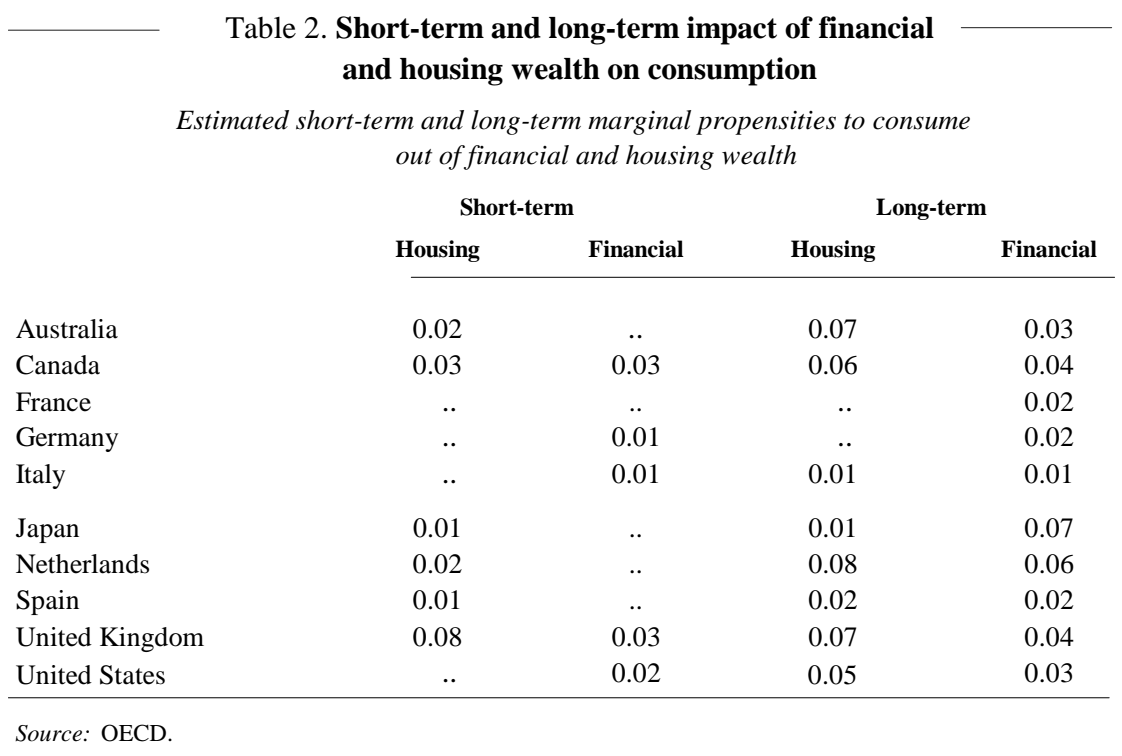

22. The dynamic specification exhibits significant error correction coefficients for all economies, with the expected sign. The speed of adjustment of consumption to the desired level of consumption appears to be relatively slow in general, though somewhat faster for Germany and Italy which are estimated with the price proxies and for Spain which has a relatively short estimating period. The gradual response speed in combination with the relatively small propensity to consumer out of wealth suggest that relatively long-lived movements in income and wealth, such as those brought on by the stock market boom in the late 1990s, can be expected to have a noticeable effect on consumption. The main exception is the

20. See for example Pichette and Tremblay (2003) for Canada, Case et al. (2001) and Benjamin et al. (2003) for the United States, Deutsche Bundesbank (2003) for Germany, OECD (2003) for the United Kingdom, Dvornak and Kohler (2003) for Australia and Ludwig and Slok (2004) for a panel of seven countries.

21. The full estimation results are presented in Annex tables 1A and 1B. 
United Kingdom, where changes in housing wealth have a large short run impact effect on consumption behaviour which "overshoots" the long run effect. ${ }^{22}$

\section{The role of mortgage debt and housing equity withdrawal}

23. The size of the long-run effect of housing wealth on consumption appears to be positively correlated with indicators of mortgage market size, such as household mortgage debt ratios, suggesting that the mortgage market is pivotal in translating house price shocks into spending responses (Figure 5, panel A). Indeed, the size of the household sector's residential mortgage debt shows large cross-country differences, with ratios to GDP currently above 60 per cent in Denmark, the Netherlands and the United Kingdom and below 25 per cent in France, Italy and Greece. These ratios have risen very substantially over the past decade, particularly where house prices have risen most (Table 3 ).

Figure 5. Marginal propensities to consume out of housing wealth and mortgage market indicators

\section{A : Mortgage debt ratios}

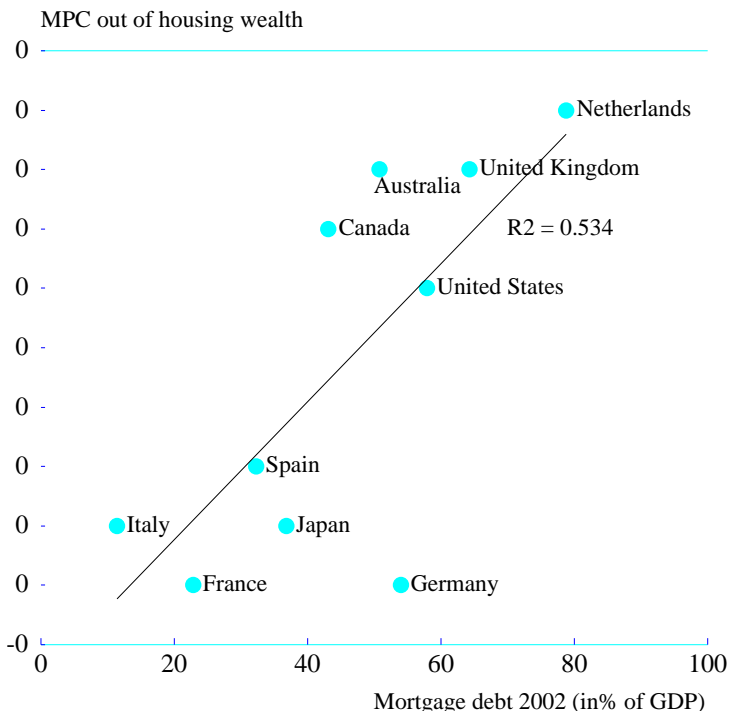

\section{B : Housing equity withdrawal}

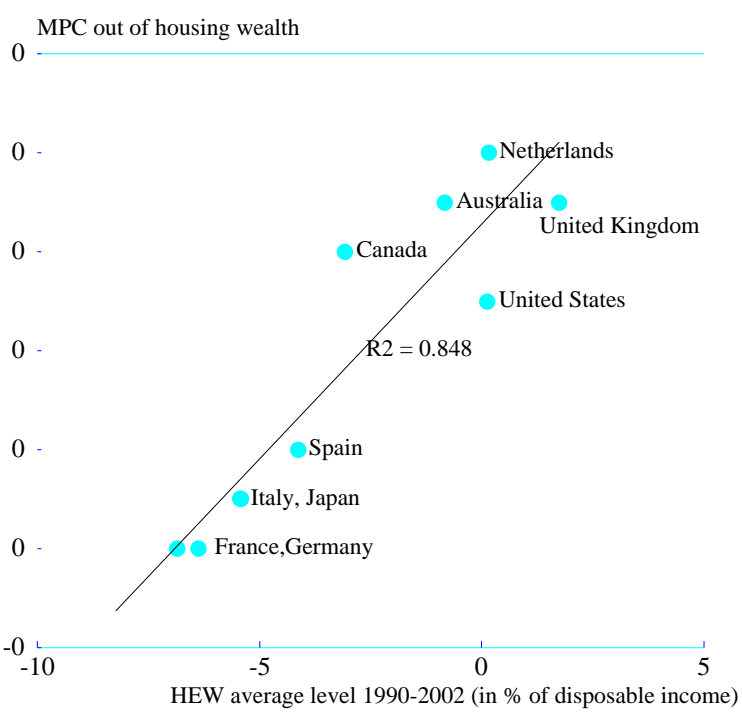

HEW average level 1990-2002 (in \% of disposable income)

Note : MPC is for marginal propensity to consume; HEW is for housing equity withdrawal.

Sources : European Mortgage Federation, United States Federal Reserve Board, Japan Statistics, United Kingdom Office for National Statistics, Bank of Canada, Bank of France, Statistics Canada, Bank of the Netherlands, Bank of Spain, European Central Bank, Reserve Bank of Australia and OECD.

24. The influence of the housing market on consumption -- as well as the rapidity of this response -depends on the extent to which homeowners are able to borrow against housing wealth. Housing equity withdrawal (HEW) is usually calculated by subtracting the household sector's residential investment from the net increment in their mortgage debt. This indicates the extent to which the household sector as a whole is extracting liquidity from the housing market. It is more likely to be positive when households are able to

22. Econometric analysis by the UK Treasury and the Bank of England, as well as similar work published in OECD (2004a), confirms that changes in housing wealth have a relatively large short-run impact on consumption behaviour which overshoots the longer-term effect. 
renegotiate existing mortgage loans or to contract second mortgages on the same property to take advantage of an increase in housing wealth. Again, the size of housing equity withdrawal is closely correlated with the impact of housing wealth on consumption (Figure 5, panel B), as well as with the level of mortgage debt across countries.

Table 3. Mortgage and housing market indicators

\begin{tabular}{|c|c|c|c|c|c|c|c|c|}
\hline & \multicolumn{2}{|c|}{$\begin{array}{l}\text { Residential mortgage debt } \\
\text { in \% of GDP }\end{array}$} & \multicolumn{2}{|c|}{ Loan-to-value ratios (\%) } & \multirow{2}{*}{$\begin{array}{c}\text { Typical loan } \\
\text { term } \\
\text { (years) }\end{array}$} & \multicolumn{3}{|c|}{ Share of owner-occupied housing (\%) } \\
\hline & 1992 & 2002 & typical & maximum & & $1980^{a}$ & $1990^{a}$ & $2002^{a}$ \\
\hline Australia & 24.2 & 50.8 & 65 & .. & 25 & 71 & 72 & 70 \\
\hline Austria &.. & .. & 60 & 80 & $20-30$ & 52 & 55 & 56 \\
\hline Belgium & 19.9 & 27.9 & 83 & 100 & 20 & 59 & 67 & 71 \\
\hline Canada & 42.7 & 43.1 & 75 & .. & 25 & 62 & 63 & 66 \\
\hline Denmark & 63.9 & 74.3 & 80 & 80 & 30 & 52 & 52 & 51 \\
\hline Finland & 37.2 & 31.8 & 75 & 80 & $15-18$ & 61 & 67 & 58 \\
\hline France & 21.0 & 22.8 & 67 & 100 & 15 & 47 & 54 & 55 \\
\hline Germany & 38.7 & 54.0 & 67 & 80 & $25-30$ & 41 & 39 & 42 \\
\hline Greece & 4.0 & 13.9 & 75 & 80 & 15 & 75 & 76 & 83 \\
\hline Ireland & 20.5 & 36.5 & 66 & 90 & 20 & 76 & 79 & 77 \\
\hline Italy & 6.3 & 11.4 & 55 & 80 & 15 & 59 & 68 & 80 \\
\hline Japan & 25.3 & 36.8 & 80 & .. & $25-30$ & 60 & 61 & 60 \\
\hline Luxembourg & $23.9^{b}$ & 17.5 & .. & 80 & $20-25$ & 60 & 64 & 70 \\
\hline Netherlands & 40.0 & 78.8 & 90 & 115 & 30 & 42 & 45 & 53 \\
\hline New Zealand & 32.6 & 56.2 &.. & .. &.. & .. & 73 & 65 \\
\hline Norway & 47.9 & 50.2 &.. & 80 & $15-20$ & 74 & 78 & 77 \\
\hline Portugal & 12.8 & 49.3 & 83 & 90 & 15 & 52 & 67 & 64 \\
\hline Spain & 11.9 & 32.3 & 70 & 100 & 15 & 73 & 78 & 85 \\
\hline Sweden & 37.5 & 40.4 & 77 & 80 & $<30$ & 58 & 56 & 61 \\
\hline United Kingdom & 55.5 & 64.3 & 69 & 110 & 25 & 58 & 65 & 69 \\
\hline United States & 45.3 & 58.0 & 78 & .. & 30 & 65 & 64 & 68 \\
\hline \multicolumn{9}{|c|}{$\begin{array}{l}\text { a) Approximate dates. } \\
\text { b) } 1994\end{array}$} \\
\hline
\end{tabular}

25. The addition of a variable representing housing equity withdrawal in the consumption equation permits the examination of this effect. The results support the hypothesis that rising HEW may have increased the consumption level in Australia, Canada, the Netherlands, the United Kingdom and the United States (Table 4) ${ }^{23}$ In these countries the marginal propensity to consume out of housing equity withdrawal (approximating a liquidity effect since this variable represents a cash flow) appears significant, and its magnitude ranges between 0.20 for the Netherlands and the United States and 0.89 for the United

23. The full estimation results are presented in Annex tables 2A and 2B. 
Kingdom. By contrast, no effect of HEW is found for France, Germany, Italy, Japan and Spain. Where the housing equity withdrawal variable is significant, it seems to capture most of the impact of housing wealth on consumption, suggesting that such impact is channelled to a large extent through greater access to liquidity. In fact, when housing equity withdrawal is included among the explanatory variables, the effect of housing wealth is no longer statistically significant. This is consistent with the fact that in the countries where housing equity withdrawal plays an important role (Australia, Canada, the Netherlands, the United Kingdom and the United States) it is also strongly correlated with house prices (Figure 6).

Table 4. Estimates of the long-term equations with housing equity withdrawal

\begin{tabular}{lccccc} 
& Australia & Canada & Netherlands & United Kingdom United States \\
\cline { 2 - 6 } & & & & & \\
Marginal propensity to consume & 0.33 & 0.06 & 0.11 & 0.08 & 0.03 \\
Financial wealth & -- & 0.05 & -- & - & - \\
Housing wealth & 0.63 & 0.63 & 0.20 & 0.89 & 0.20 \\
Housing equity withdrawal & & & & & $1977: 12002: 2$ \\
Sample & $1989: 11999: 2$ & $1970: 12002: 2$ & $1981: 22003: 1$ & $1978: 12002: 2$ & 19720 \\
\hline
\end{tabular}

Source: $O E C D$.

\section{Structural factors behind differences in housing wealth effects}

26. In summary, it is possible to identify a group of countries (Australia, Canada, the Netherlands, the United Kingdom and the United States) where changes in housing wealth have a significant effect on consumption, exceeding the effect of changes in financial wealth. This effect seems to work mainly through the interaction of house prices and mortgage lending. By contrast, in France, Germany, Italy, Japan and Spain the housing wealth effect appears to be smaller or in some cases statistically insignificant, and HEW does not help explain consumption behaviour. The different role of housing equity withdrawal in the two groups of countries suggests that the mortgage market is pivotal in translating house price shocks into spending responses. However, such aggregate indicators are the result of deeper structural differences in the functioning of national housing and mortgage markets, which may help explain observed crosscountry differences in marginal propensities to consume out of housing wealth.

27. In particular, consumption responses to changes in housing wealth can be expected to be higher, ceteris paribus, in countries where:

- Financial markets provide easy access to mortgage financing and to financial products that facilitate equity withdrawal.

- There is a high rate of owner-occupation, which implies a wider distribution of housing wealth.

- There are low housing transaction costs and housing wealth is exempted from capital gains taxes, both of which would encourage owners to perceive housing assets as more liquid. 
Figure 6. Housing equity withdrawal and real house prices

Housing equity withdrawal, in $\%$ of disposable income (left scale)

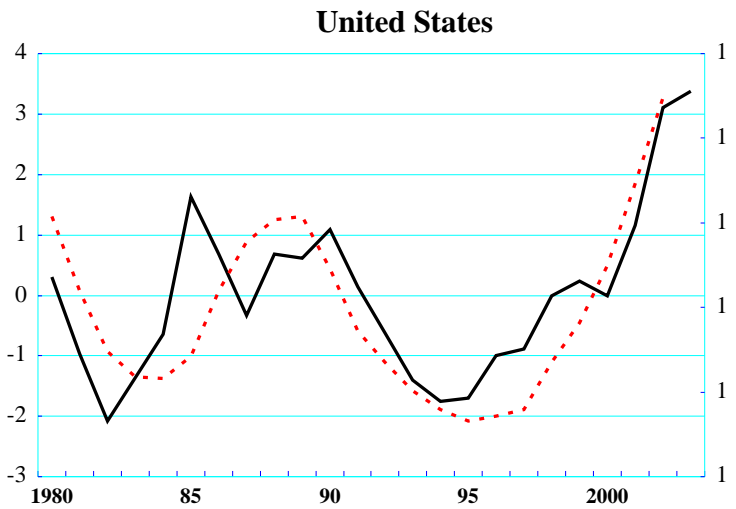

Real house prices, level relative to trend (right scale)
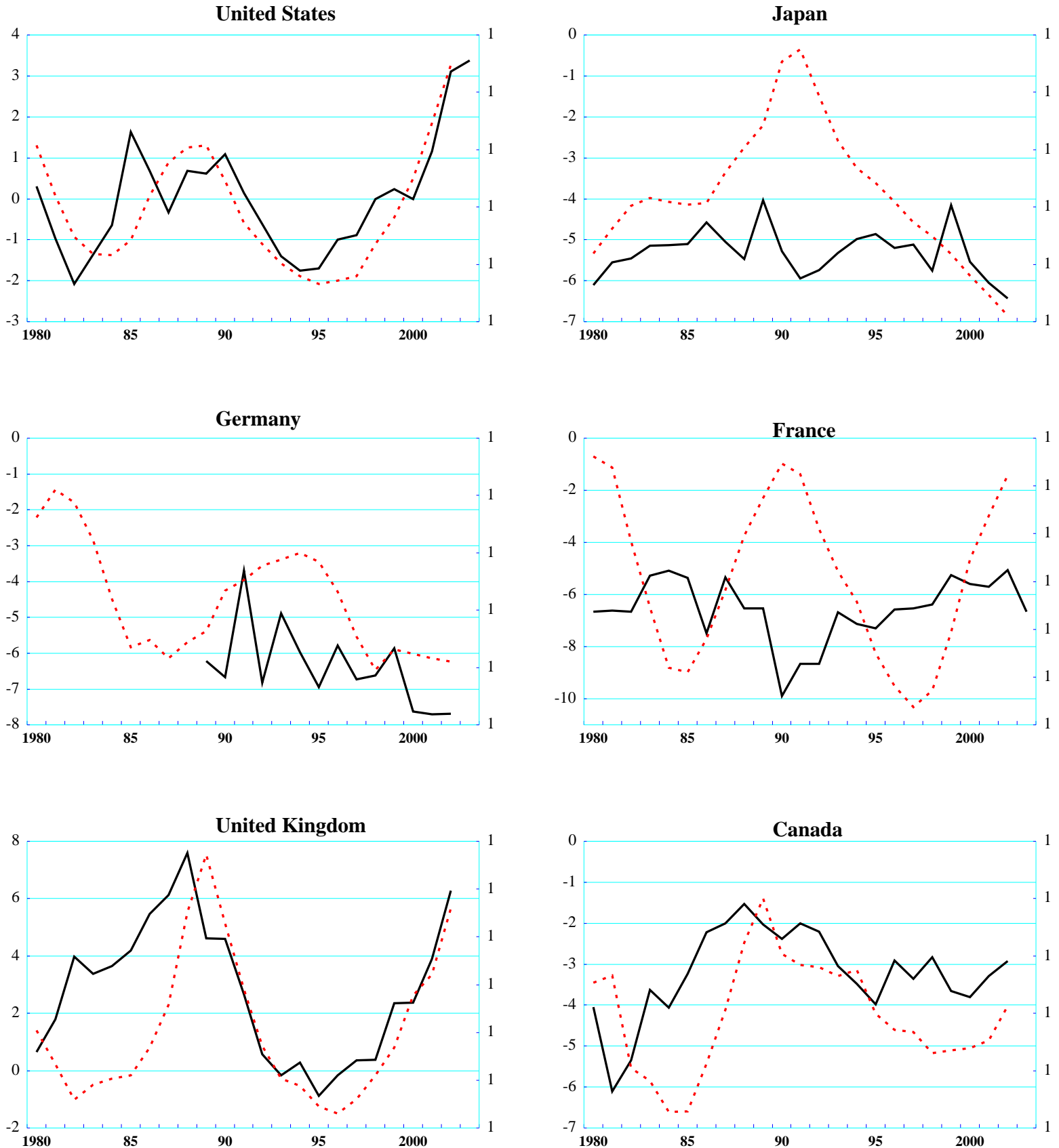
Figure 6 (cont.). Housing equity withdrawal and real house prices
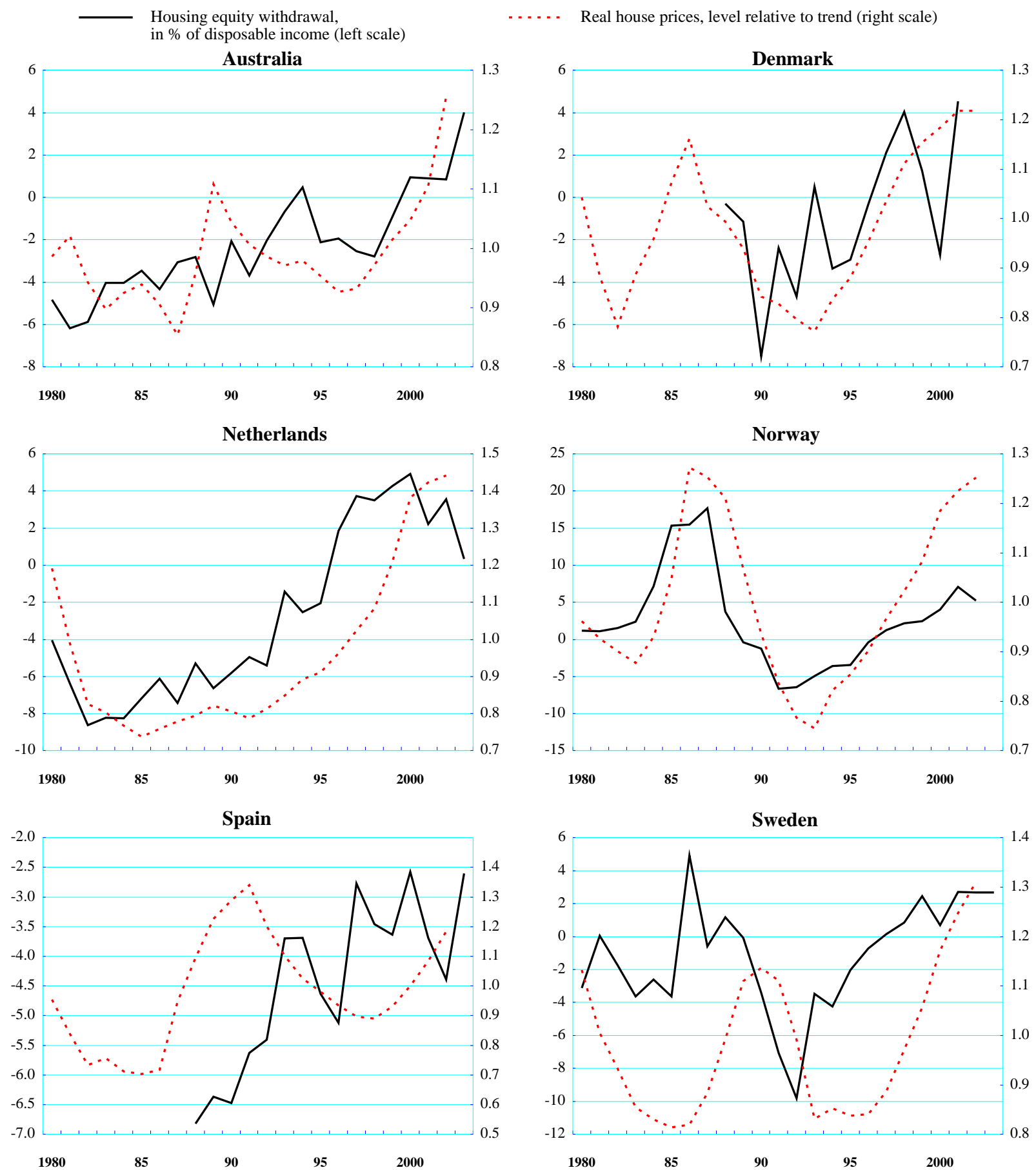

Sources: United States Federal Reserve Board, Japanese Annual National Account, United Kingdom Office for National Statistics, Bank of Canada, Bank of France, Statistics Canada, European Mortgage Federation for Norway, The Netherlandsche Bank, Bank of Spain, European Central Bank, Reserve Bank of Australia, Swedish Riksbank and OECD 


\section{Importance of mortgage market "completeness"}

28. In general, less regulated and more competitive mortgage markets can be expected to offer a greater variety of mortgage products, to be able to serve a broader range of borrowers and to apply lower mortgage interest rate spreads. A systematic cross-country comparison along these dimensions is available only for a group of eight European countries. ${ }^{24}$ Among these, Denmark, the Netherlands and the United Kingdom appear to have the most complete mortgage markets in terms of the range of products offered, such as second mortgages and equity release products, as well as a choice between alternative interest rate adjustment and repayment structures (Table 5). They are also able to cover a broader range of potential borrowers, including for example younger or older households, and borrowers unable to certify their income. Some of these product or borrower coverage options exist also in the traditionally less sophisticated markets such as Italy and Germany, but they are less common, having been introduced more recently.

29. A synthetic measure of these characteristics of mortgage markets is the "completeness" index presented in Table 5. The index is calculated as a weighted average of several criteria, including levels of loan-to-value ratios, product variety, borrower types and loan purposes covered, as well as distribution channels and the quality of information and advice offered to customers. ${ }^{25}$ The close relationship of mortgage market "completeness" with real house price/consumption correlations (Figure 7, panel A) and housing equity withdrawal (panel B) confirm the crucial role played by the provision of liquidity in connection with housing assets.

30. The composition of mortgages as between fixed-rate and variable-rate is also potentially important, since mortgage rates can react differently depending on what is happening to the yield curve. Not surprisingly, in countries with mostly fixed-rate mortgages the pass-through to rates on new loans depends on whether the change in short rates is accompanied by a shift in long rates (de Bondt et al., 2003). The short-term interest rate has a stronger impact in countries where variable-rate mortgages prevail, while the long-term rate is relevant in those with mostly fixed-rate mortgages. In the latter case it may be costly to refinance. In France, for example, fixed rate mortgages have typically been available for a term of 15 years, but refinancing penalties amount to up to six months interest or 3 per cent of the balance that is being prepaid. That makes refinancing unattractive when interest rate declines are small. In Germany, rates on mortgages are typically fixed for ten years, and it is very difficult to refinance. The Italian market is a hybrid of fixed and floating rates. By contrast, in Denmark and the United States, where most loans are also fixed-rate, penalty-free prepayment options are common, as mortgage lending is largely funded through callable mortgage-backed securities. In the United Kingdom, mortgage rates are usually variable and interest rate changes feed through rapidly to changes in monthly service payments.

24. See Mercer Oliver Wyman (2003). The countries covered are: Denmark, France, Germany, Italy, the Netherlands, Portugal, Spain and the United Kingdom.

25. See Mercer Oliver Wyman (2003) for further details. 
ECO/WKP(2004)17

Table 5. Mortgage market completeness: range of mortgage products available and of borrowers served in eight European countries

a) LTV ratios

Typical

Maximum

b) Variety of mortgage products

Rate structure

Variable

Variable (referenced)

Discounted

Capped

Range of fixed terms

$2-5$

$5-10$

$10-20$

$20+$

Repayment structures

Amortising

Interest only

Flexible

Fee-free redemption ${ }^{\text {a }}$

Full yield maintenance fee

c) Range of borrower types and mortgage purposes

\section{Borrower type}

Young household $(<30)$

Older household (>50)

Low equity

Self-certify income

Previously bankrupt

Credit impaired

Self employed

Government sponsored

Purpose of loan

Second mortgage

Overseas holiday homes

Rental

Equity release

Shared ownership

\begin{tabular}{cccccccc} 
Denmark & France & Germany & Italy & Netherlands & Portugal & Spain & $\begin{array}{c}\text { United } \\
\text { Kingdom }\end{array}$ \\
\hline 80 & 67 & 67 & 55 & 90 & 83 & 70 & 69 \\
80 & 100 & 80 & 80 & 115 & 90 & 100 & 110
\end{tabular}

Mortgage market completeness index ${ }^{b}$

$\begin{array}{cccccccc}* * & * * & * * & * * & * * & * * & * * & * * \\ * * & * * & - & * * & * * & * * & * * & * * \\ - & * * & - & * & - & - & * * & * * \\ * * & * * & * & * & * * & - & * & * * \\ * * & * * & * * & * * & * * & * & * & * * \\ * * & * * & * * & * * & * * & * & * & * \\ * * & * * & * * & * & * * & - & * & * \\ * * & * & * & * & * & - & * & - \\ * * & * * & * * & * * & * * & * * & * * & * * \\ * & * * & * * & * & * * & - & - & * * \\ * & * * & - & * & * * & - & * & * * \\ * * & - & - & - & - & - & - & * \\ * * & * & * * & * & * * & * & * & *\end{array}$

Note: Readily available means that products are actively marketed with high public awareness; Limited availability means that only a small subset of lenders provide this product, often with additional conditions; No availability means that no lenders surveyed offered the product. See Mercer Oliver Wyman (2003) for further details on the sample and criteria of the survey.

Key: ** Readily available * Limited availability - No availability

a) On fixed-rate products only.

b) See Mercer Oliver Wyman (2003) for details on the calculation of the index.

Source: Mercer Oliver Wyman (2003). 
Figure 7. Effects of mortgage market completeness
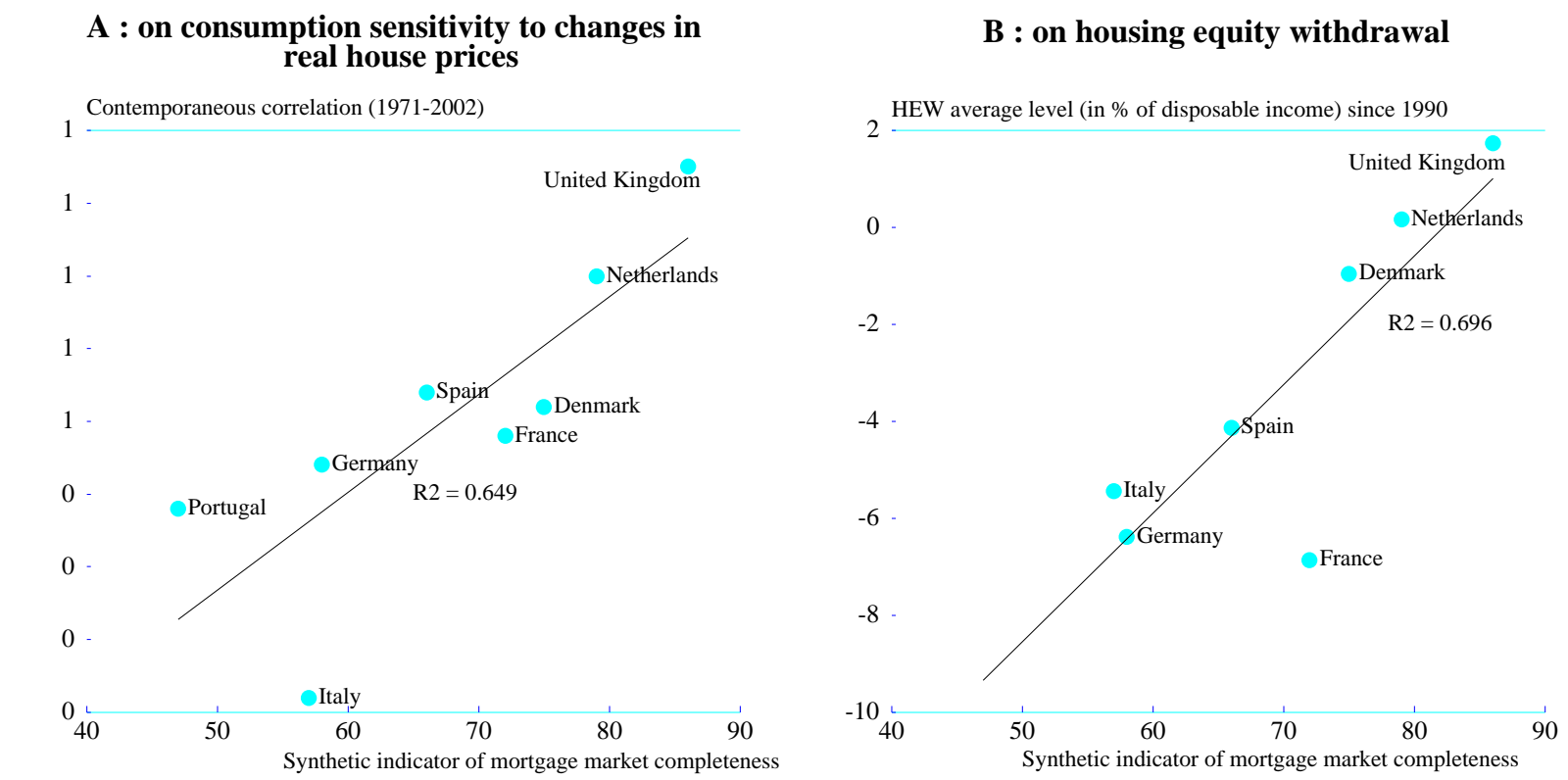

Note : HEW is for housing equity withdrawal.

The synthetic indicator of mortgage market completeness is presented in Table 5 (for additional information see Mercer, Oliver,

Wyman, 2003). For Portugal, the contemporaneous correlation between consumption and real house price change is calculated over the period 1989-2001, due to limited data availability.

Sources : Mercer, Oliver, Wyman (2003), United States Federal Reserve Board, Japan Statistics, United Kingdom Office for National Statistics, Bank of Canada, Bank of France, Statistics Canada, Bank of the Netherlands, Bank of Spain, European Central Bank, Reserve Bank of Australia, OECD.

31. On the other hand, cross-country differences in mortgage rate spreads over market rates for the relevant maturity, which are proximate indicators of efficiency, are not large, having narrowed significantly over the past ten years. Once fees are taken into account and adjustment is made for credit risk and for the value of prepayment options, spreads vary within a relatively narrow range (70-135 basis points) among the countries considered in Figure $7 .{ }^{26}$ The remaining differences reflect mostly product structure and operating and funding costs, plus some distorting influences such as cross-subsidisation with other products and the presence in some countries of government-owned lenders with low cost of capital. Spreads are highest in Italy, which also has the highest operating costs. In Denmark and Germany, the existence of well-developed markets for mortgage-backed securities has contributed to contain funding costs for fixed-rate loans.

32. Two key indicators of mortgage market ability to provide access to financing are typical or maximum loan-to-value (LTV) ratios and mortgage terms (Table 3). Not surprisingly, across countries both are correlated with the size of mortgage debt. ${ }^{27}$ In fact, high LTV ratios allow borrowers to take out more debt, and longer repayment terms are then needed to keep debt service-to-income ratios affordable.

26. An earlier study by Diamond and Lea (1992) covering four of the eight countries considered in the Mercer Oliver Wyman (2003) study (Denmark, France, Germany and the United Kingdom) found adjusted spreads ranging between 120 and 276 basis points.

27. Among the countries reported in Table 3, the correlation coefficient of mortgage ratios with typical LTV ratios is 0.48 ; with typical mortgage terms it is 0.74 . 
Even if housing loans are taken solely for house purchase, this adds to the household sector's liquidity. Maximum LTV ratios above 100 per cent exist in the Netherlands and the United Kingdom, although they are typically lower. Typical LTV ratios are particularly low in Italy. Equity withdrawal is further facilitated where mortgage products specifically designed for this purpose are widely marketed, as is the case particularly in Australia, the Netherlands, the United Kingdom and the United States, but also in several Nordic countries. By contrast, such products are either not offered or not widely marketed in France, Belgium and in Southern European countries.

33. The above differences are likely to reflect the lender's perception of the risk connected to mortgage loans. An important element in this regard is the legal protection of collateral. The administrative costs and the time required to realise the collateral's value in the event of default differs considerably across countries (Table 6). In Belgium, France, Portugal and especially Italy the length of legal procedures is probably a key factor discouraging banks from making larger loans relative to the value of the property and from lending to higher-risk borrowers. In a number of OECD countries there are also regulatory ceilings to LTV ratios, and in most of them a loan's LTV ratio influences its weighting for the purpose of capital adequacy requirements, so that high-LTV loans are more costly to fund (see Annex table 3). Regulatory limits are particularly binding in Germany, being combined with a mandatory loan valuation method that implies an additional discount of 20 to 25 per cent relative to market prices. Moreover, loans with LTV ratios above the 60 per cent ceiling are also ineligible for inclusion in mortgage-backed securities (or can be included, up to an LTV of 80 per cent, but the portion of the loan above 60 per cent is not recognised for collateral purposes). ${ }^{28}$

\begin{tabular}{|c|c|c|}
\hline & $\begin{array}{l}\text { Usual time required }^{a} \\
\text { (months) }\end{array}$ & $\begin{array}{l}\text { Administrative costs }{ }^{b} \\
\quad \text { (in per cent) }\end{array}$ \\
\hline Austria & 6 & .. \\
\hline Belgium & 18 & 18.70 \\
\hline Denmark & 6 & .. \\
\hline Finland & $2-3$ & 2.5 \\
\hline France & $15-25$ & 7 \\
\hline Germany & 12 & 4.2 \\
\hline Greece & 3 & 16 \\
\hline Ireland & $11-14$ & $8.6-10.6$ \\
\hline Italy & $60-84$ & $\cdot$. \\
\hline Netherlands & 6 & 3 \\
\hline Portugal & $18-30$ & 8 \\
\hline Spain & $7-9$ & 17 \\
\hline Sweden & $4-6$ & 5 \\
\hline United Kingdom & $8-12$ & $2.6-7$ \\
\hline United States & 8.4 & 11.5 \\
\hline \multicolumn{3}{|c|}{$\begin{array}{l}\text { a) Total time from the writ of execution (in the countries where the mortgage must be given executory power by a court) } \\
\text { to the distribution of the proceeds to creditors. } \\
\text { b) Costs usually include both fixed and variable components. Here they are calculated for a property value of } € 100000 \text {. } \\
\text { They do not include lost interest during the procedure. } \\
\text { Sources: For EU countries: EMF (2002); for the United States: Department of Housing and Urban Development (1996). }\end{array}$} \\
\hline
\end{tabular}

28. See Contact Group on Asset Prices (2002). 
34. Though mortgage markets have been evolving rapidly in most OECD countries, including those where they were least developed, differences are still considerable as regards the range of potential borrowers reached and the variety of needs covered. If mortgage debt ratios can be taken as a summary indicator of market size, their dispersion has actually increased from 1992 to 2002 . Thus, it seems possible to distinguish between a group of countries where mortgage markets provide ample access to liquidity (Australia, Canada, the Netherlands, the United Kingdom, the United States and Nordic countries) and others where this is still limited (particularly Italy and France). The picture is more mixed for Germany -- where basic mortgages with long repayment terms are very affordable but product range is limited and LTV ratios are low -- and for Spain, where the market seems to have been developing very rapidly.

\section{Influence of owner-occupied housing}

35. Potentially amplifying the importance of mortgage-market structure is the extent of owner occupation. Housing tenancy structures differ considerably across OECD countries. Broadly speaking, the share of owner-occupied housing is very high in Southern European countries, relatively low in Austria, Germany, the Netherlands and in some Nordic countries and around two-thirds in most other countries (Table 3). In part, these differences reflect tax incentives (discussed below). They also reflect differences in access to mortgage financing. Access to mortgage markets seems to allow households to achieve homeownership earlier: in the Netherlands and in the United Kingdom households in the 25-29 age group are more likely to be homeowners, relative to the national average, than in France, Germany, Italy or Spain. In practice, however, some of the countries with the highest owner-occupation rates -- such as Italy and Spain -- are among those that have, or had until recently, the least developed mortgage markets. This suggests that other mechanisms for providing access to home-ownership are available in these countries, like for example inter-generational wealth transfers. Thus, while owner-occupation may be a necessary condition for a housing wealth channel to open up, it is not a sufficient one, and the cross-country correspondence between owner-occupation and the sensitivity of consumption to real house prices is weak.

\section{Housing transaction costs and the taxation of housing capital gains}

36. Housing transaction costs also differ considerably across countries. Taxes, such as stamp duties are one component (Annex table 4). In addition, the fees to be paid to intermediaries can be set directly by regulations or be influenced by regulations on entry into the market for real estate services. Estimates of housing transaction costs for different countries on a comparable basis are difficult to find. Those available are not very recent and cover only a limited number of countries. Those shown in Figure 8 , from the Danish Ministry of Business, indicate that such costs are generally higher in continental European countries than in Nordic countries. Data from other sources indicate that transaction costs are among the lowest in the United Kingdom. ${ }^{29}$ The connection between housing transaction costs and the strength of the house-price/consumption correlation is difficult to demonstrate from this small sample. But the presumption is that higher costs operate to impede the housing sector/consumption transmission mechanism by making housing assets less liquid.

29. For example, 1993 data from Woolwich Building Society (reproduced in MacLennan et al., 1999) indicate that transaction costs tend to be very high in France and Spain; lower, but still substantial, in Germany, Italy and the United States; and much lower in the United Kingdom. However, because of the definitions used and the time to which they refer, these data are not fully comparable with those presented in Figure 6. Other data, such as those published in The Economist, 3 September 1998 (referring to non-tax transaction costs only) yield a broadly similar ranking of countries. 
Figure 8. Housing transaction costs

Transaction costs for sales of medium sized houses

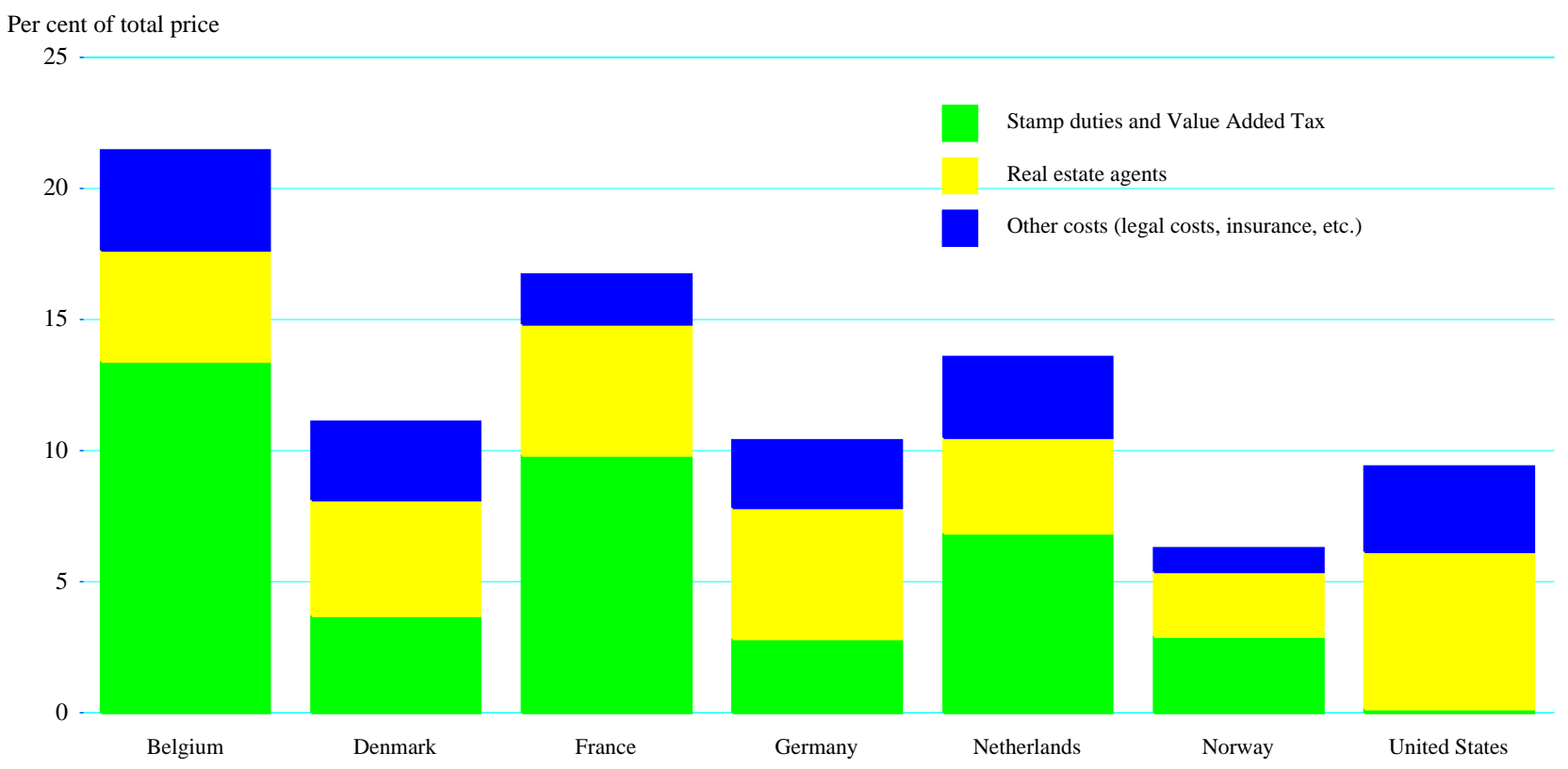

Source : Denmark, Ministry of Business, 'Boligrapport' 1997.

37. The taxation of capital gains on housing assets can be seen as having similar effects to transaction costs if the tax is levied when the gains are realised, as is usually the case. However, while most OECD countries apply capital gains taxes to residential property, a majority exempt owner-occupied dwellings that are the owner's main residence (Annex table 4) ${ }^{30}$ In the few countries where gains are taxed but no exemption exists for principal owners, such as Norway, Sweden and Austria, this tax may be perceived as a significant additional transaction cost. In Spain and Portugal, capital gains on housing are exempt from the tax if the proceeds are reinvested.

\section{The determinants of house price variability}

38. While there is a clear connection between real house prices and aggregate demand, the extent to which this can add to economic resilience depends on the correlation of house prices with the output cycle. As noted, the lags between output fluctuations and real house prices vary both from one cycle to another and between countries, and it is these lags which determine the degree to which house price movements are pro- or counter-cyclical. This section examines the factors which help to determine these phenomena and draws some policy implications from them.

30. In some countries, such as Austria, Belgium, Finland and Germany, this exemption has been available only if the property is held for a minimum number of years (e.g. five to ten years), a provision that is intended to encourage long-term, non-speculative investment in housing. 


\section{Housing markets and monetary policy transmission}

39. The implications of house price movements for the transmission of monetary policy are of particular interest. Changes in policy-determined interest rates can influence household expenditure both through "income effects" and "wealth effects", which arise from associated movements in real house prices and hence from changes in housing equity. The "wealth channel" in this case would involve an initial link in which interest rates impact on real house prices, as changes in the relative cost of housing services lead to shifts in demand for housing.

40. House prices do, indeed, appear to be affected by interest rate changes, and there is evidence that the strength and speed of this transmission differ considerably across countries. The impact of interest rates on house prices seems to be both stronger and more rapid in countries with more developed mortgage markets (Australia, Ireland, the Netherlands, the United Kingdom and the United States, as well as Nordic countries and Japan) as compared with most continental European countries. ${ }^{31}$ It is probable a priori that such differences can be ascribed to the same mortgage-market channels that determine the strength of housing wealth effects on spending, such as the costs of refinancing and the flexibility of the mortgage market in response to changes in housing demand. But cross-country variations in the link between monetary policy and house prices may also reflect such factors as differences in the elasticity of housing supply, inflation expectations and housing tax regimes.

41. The lags that characterise the interactions between house prices, interest rates and the business cycle help determine the extent to which house price movements have a stabilising effect on the cycle. Lags are present not only in consumption's response to changes in housing wealth, as discussed in Section 3 , but also in house prices' response to economic activity (mediated via its effect on housing demand) and to interest rates, as mentioned in the presentation of the "stylised facts" in Section 2. In addition, interest rates respond to the business cycle, in ways that can differ from one cycle to another depending in particular on inflation behaviour. In practice, several patterns may be observed. For example, a buoyant housing market may have a pro-cyclical effect during the last part of an upswing -- as was the case in the late 1990s in many countries -- but then continue for some time after the cyclical turning point, helping to soften the downturn as in 2001-2002. However, there have also been instances, particularly when the previous run-up had taken house prices to unsustainable levels and had been accompanied by a large rise in household indebtedness, where a protracted property market slump contributed to deepen and prolong a cyclical downturn (e.g. the United Kingdom and some Nordic countries in the early 1990s).

42. Thus, having a strong transmission from housing wealth to consumption will tend to be most conducive to greater resilience where house prices fluctuations are not closely synchronised with the business cycle and where structural rigidities do not interact with interest rate shifts to push house prices to unsustainable levels. From this point of view, it helps that the institutional conditions associated with relatively strong housing wealth effects -- in particular, a well-developed and flexible mortgage market -tend to favour both a strong and relatively quick transmission of monetary impulses to the housing market and efficiency in the housing market. This means that, in assessing the overall impact of the housing market on resilience in the face of macroeconomic shocks, the degree of house price variability arising from structural rigidities in the housing market also needs to be considered.

31. Tsatsaronis and Zhu (2004). 


\section{Structural determinants of house price variability}

43. The variability of house prices is likely to be higher if the supply of housing is price-inelastic and if the demand for housing is subject to large shocks. There is evidence that supply rigidities are indeed important (Figure 9, panel A). The housing stock is given in the short run, while its long-run elasticity with respect to relative price changes is likely to depend mainly on the natural or policy-induced scarcity of urban land. For example, several studies have found that in the United Kingdom cumbersome local zoning regulations and a slow authorisation process are among the reasons for the rigidity of housing supply, and an important factor underlying both the trend rise of house prices in that country and their high variability. ${ }^{32}$ Similar factors affect house price dynamics in Luxembourg, the Netherlands and Spain (OECD, 2003a, 2003b and 2004b).

44. Housing demand shifts can reflect a combination of structural factors. Institutional and tax parameters are important not only because frequent changes can be themselves the source of house price variability, but also because their settings influence economic agents response to actual and expected macroeconomic variables. The literature has emphasised that one important determinant of house price variation is inflation expectations, changes in which affect the relative returns on alternative investments. Indeed, across countries house price variability appears to be correlated with inflation variability (Figure 9, panel B), although the relevance of this result is much reduced in a low-inflation environment. ${ }^{33}$ However, the scope for speculative behaviour is increased by several features of housing and mortgage markets which have been characterised as favouring economic resilience above. For example, mortgage markets characterised by high loan-to-value ratios make it easier for investors to take leveraged positions, while low transaction costs and the exemption of housing assets from capital gains taxation could increase the expected net profits from speculative housing investments.

45. Among the structural factors that have been identified as a potential source of house price variability, negative tax wedges resulting from the tax deductibility of mortgage interest appear to be correlated with house price variability, at least among European Union countries (Figure 9, panel C). ${ }^{34}$ This would seem to confirm that tax incentives can make some housing markets more prone to cycles by lowering the cost of leveraging the financing of housing investment. Some correlation exists also between house price variability and a low level of housing transaction costs, although reliable data on these are available for too few countries for the relationship to be regarded as robust (Figure 9, panel D) ${ }^{35}$

\section{Housing market efficiency and resilience to shocks}

46. In sum, the benefits to resilience from liberalising housing and mortgage markets and reducing housing transaction costs would appear to be enhanced where supply-side conditions are favourable. From the above evidence it would seem that policies which create a low and stable inflation environment, which

32. See OECD (2004a), Barker (2003) and Bramley (1993).

33. These variabilities are calculated over a relatively long period (1970-2002) so that the results reflect to a large extent the past history of macroeconomic instability in a number of countries.

34. The tax wedges shown on the figure also take into account property taxes on housing (van den Noord, 2004).

35. Transaction costs have two effects of opposite sign: on the one hand they tend to make housing demand price inelastic, which tends to exacerbate house price movements; on the other hand, they also make demand less reactive to price expectations, thus reducing the scope for speculative bubbles. 
Figure 9. Real house price variability and selected explanatory variables

\section{A : Price elasticity of housing supply}

12 Standard deviation of annual real house price changes (1971-2002)

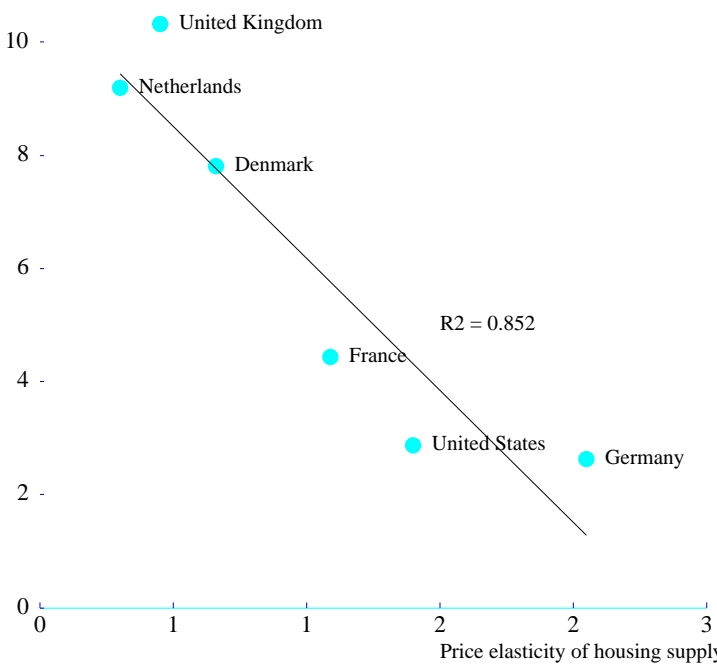

C : Tax wedge on mortgage interest

12 Standard deviation of annual real house price changes (1971-2002)
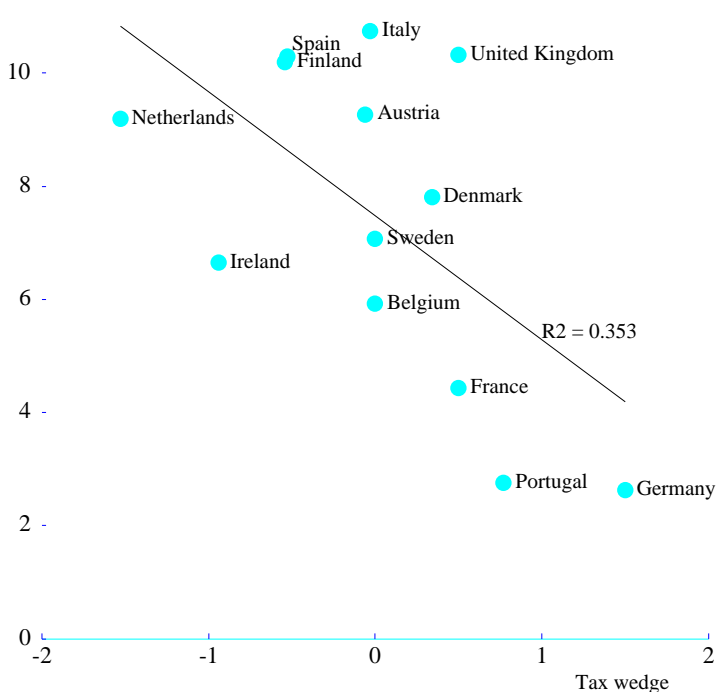

\section{B : Consumer inflation variability}

12 Standard deviation of annual real house price changes (1971-2002)

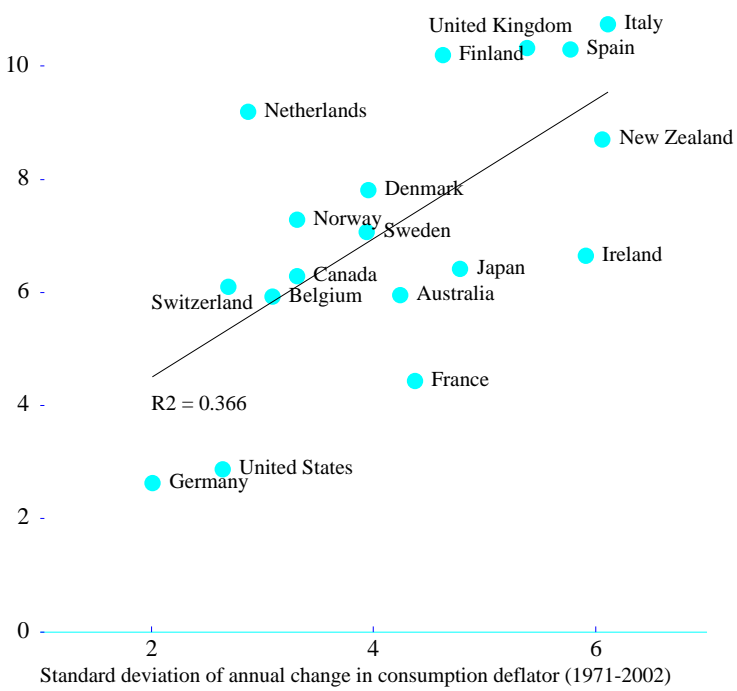

D : Housing transaction costs

12 Standard deviation of annual real house price changes (1971-2002)
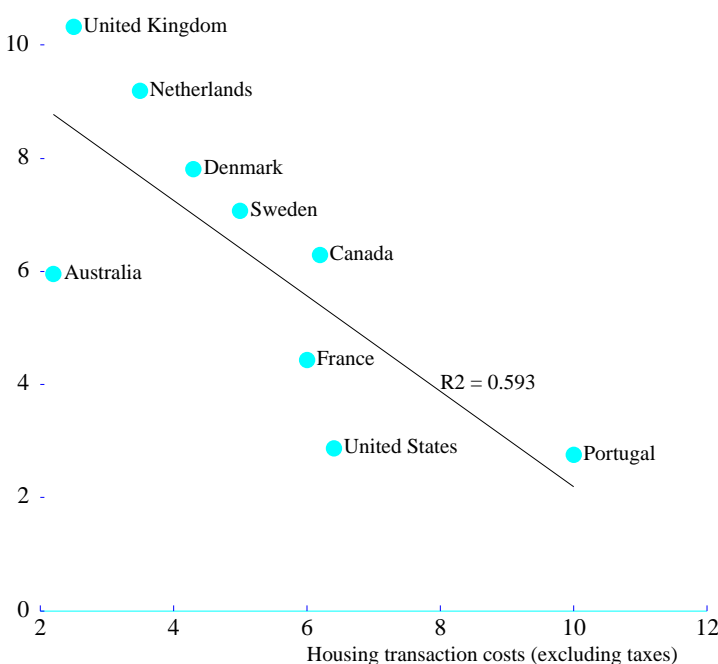

Note : In panel C, the tax wedge is defined as the difference between the after-tax and the pre-tax real interest rate on mortgage loans. It also incorporates the effect of property taxes. Thus, a low or negative tax wedge indicates a more favorable tax treatment of mortgage interest.

Sources : Bank for International Settlements and Quotable Value New Zealand for house price data; the Economist for data on housing transaction costs; Swank, Kakes and Tieman (2002) for estimates of price elasticities of housing supply; Van den Noord (2004) for tax wedges on mortgage interest and OECD for data on consumer inflation variability. 
enhance the efficiency of the housing market via a neutral tax structure, and which encourage housing supply responsiveness by avoiding unnecessarily restrictive zoning regulations can act to ensure that asset price movements in the housing market are based on solid fundamentals.

47. While removing regulatory and tax-induced distortions to housing and mortgage markets can be expected to yield both long-run benefits in terms of efficient resource allocation and greater resilience to shocks, the sequencing of structural reforms is also important. Inappropriate sequencing can generate macroeconomic instability in the short run and lead to the accumulation of imbalances, whose subsequent re-absorption may require a lengthy and costly adjustment process. For example, during the 1980s in several Nordic countries financial market deregulation took place in a context still characterised by large tax subsidies to mortgage borrowing and inadequate prudential supervision. This gave rise to a pronounced house price cycle fuelled by over-lending, and eventually led to costly bank bailouts and a protracted period of balance sheet consolidation in both the household and the financial sector.

48. Even in the absence of ill-timed policy reforms, the possibility that speculative bubbles may emerge in the housing market cannot be ruled out and needs to be guarded against. Some of the special characteristics of the housing market that set it apart from other asset markets - a prevalence of small investors; the absence of derivatives and short-selling; the heterogeneity and indivisibility of the traded asset, and low transaction frequency -- tend to create some degree of inertia in price movements and to exacerbate informational problems. They may also make it easier for prices to be driven by expectations that depart from fundamentals. Several studies have documented a tendency of house price expectations to be of the extrapolative kind. ${ }^{36}$ For these reasons, supervisory authorities must continue to ensure that the prudential framework is also resilient, by discouraging excessive risk-taking on the part of lenders and monitoring the possible emergence of financial fragilities in balance sheets in situations where asset prices may be subject to large corrections.

36. Most of the empirical literature on housing market efficiency (see Cho, 1996, for a survey) finds that both house prices and excess returns exhibit positive serial correlation in the short run. Consistent with this, Muellbauer and Murphy (1997) find that, for the United Kingdom, lagged house price changes are a significant explanatory variable for the current level of house prices. And Case and Shiller (2003) report the results of surveys conducted in 1988 and in 2003 among home buyers in four US cities, which seem to indicate that large expected long-term capital gains and low perceived risk play an important role in decisions to buy a house at times of rising prices. 


\section{ANNEX I - STATISTICAL TESTS}

49. This annex describes the statistical tests conducted in this study. For each variable, using the Augmented Dickey Fuller tests, the non-stationarity condition was tested. Subsequently, tests on the cointegrating relationships were performed. The results are discussed below.

50. To test for unit roots, the Augmented Dickey Fuller test was applied. A constant was included in the test and the lag structure was chosen by the Schwarz Information Criterion. Results are reported in Table A1. For all countries, the ADF test rejects the null hypothesis of a unit root in first differences for the logarithm of real private consumption (lcpv) and the logarithm of the adjusted real human income (lydrha) or of the real disposable income (lydrh). With the exception of the United Kingdom, the financial and the housing wealth variables were found to be integrated of the first order. In the United Kingdom, where the sample is relatively short, test statistics cannot reject the null hypothesis that the real housing wealth component is I(2). For all countries, the ADF test rejects the null hypothesis of a unit root in first difference for real house prices, inflation, the unemployment rate and the real short term interest rate. The exception being Spain where the real short term interest rate in first differences is not stationary. The critical values (one-sided p-values) for unit roots tests are from MacKinnon (1996).

51. The Engle and Granger (1987) two-step method was used to test for cointegration. The test amounts to testing for a unit root in the residuals of a first stage regression using the ADF test. The critical values associated with the test should be taken from Davidson and MacKinnon (1993) and depend on the number of explanatory variables. No constant were included in the test and the lag structure were chosen by the Schwarz Information Criterion. The results are reported in Table A2. The null hypothesis of no cointegration relationship is rejected for all countries, although at the 10 per cent level for Japan.

Table A2. Cointegration test

\begin{tabular}{ll}
\hline & \\
Australia & $-5.86 * *$ \\
Canada & $-5.27 * * *$ \\
France & $-4.50 * * *$ \\
Germany & $-4.57 * * *$ \\
Italy & $-5.01 * * *$ \\
Japan & $-4.06 *$ \\
Netherlands & $-5.45 * * *$ \\
Spain & $-4.45 * *$ \\
United Kingdom & $-4.50 * *$ \\
United States & $-5.42 * * *$ \\
\hline Note: *, ** and *** indicate statistical significance at the $10 \%, 5 \%$ and $1 \%$ level \\
$\quad$ respectively. Critical values for the residual tests of non cointegration \\
$\quad$ are from Davidson and MacKinnon (1993). \\
\hline
\end{tabular}


Table A1. Augmented Dickey-Fuller test

\begin{tabular}{|c|c|c|c|c|c|c|c|c|c|c|}
\hline & \multicolumn{2}{|c|}{ Australia } & \multicolumn{2}{|c|}{ Canada } & \multicolumn{2}{|c|}{ France } & \multicolumn{2}{|c|}{ Germany } & \multicolumn{2}{|r|}{ Italy } \\
\hline & Level & $\begin{array}{c}1 \text { st } \\
\text { difference }\end{array}$ & Level & $\begin{array}{c}1 \text { st } \\
\text { difference }\end{array}$ & Level & $\begin{array}{c}1 \text { st } \\
\text { difference }\end{array}$ & Level & $\begin{array}{c}1 \text { st } \\
\text { difference }\end{array}$ & Level & $\begin{array}{c}1 \text { st } \\
\text { difference }\end{array}$ \\
\hline lcpv & -0.37 & $-6.76 * * *$ & -1.65 & $-5.26 * * *$ & -2.28 & $-4.16 * * *$ & -1.67 & $-3.19 * *$ & -2.08 & $-4.36 * * *$ \\
\hline lydrha & -2.24 & $-8.59 * * *$ & -2.53 & $-3.06 * *$ & -4.48 & $-4.86 * * *$ & -1.32 & $-7.94 * * *$ & -0.78 & $-4.72 * * *$ \\
\hline lydrh & -1.96 & $-10.47 * * *$ & $-3.19^{* *}$ & $-4.89 * * *$ & -1.14 & $-4.86 * * *$ & -1.48 & $-3.86 * * *$ & -2.75 & $-3.71 * * *$ \\
\hline $\operatorname{lnfwr}$ & -1.02 & $-4.25 * * *$ & -0.63 & $-5.91 * * *$ & -0.92 & $-5.53 * * *$ & - & - & - & - \\
\hline lnhwr & -1.10 & $-4.99 * * *$ & -1.13 & $-7.35 * * *$ & -3.65 & $-3.79 * * *$ & - & - & & - \\
\hline ltotmkr & -0.97 & $-6.41 * * *$ & -1.21 & $-8.57 * * *$ & 0.20 & $-6.00 * * *$ & -1.35 & $-5.01 * * *$ & -0.61 & $-4.87 \quad * * *$ \\
\hline lhpr & 0.32 & $-4.34 * * *$ & -1.96 & $-6.02 * * *$ & $-3.05 *$ & $-2.79 *$ & -2.62 & $-3.00^{* *}$ & -2.90 & $-6.50 * * *$ \\
\hline inf & -2.27 & $-5.97 * * *$ & -1.80 & $-5.77 * * *$ & -1.39 & $-4.29 * * *$ & -1.64 & $-6.89 * * *$ & -1.61 & $-6.51 * * *$ \\
\hline unr & -1.78 & $-5.71 * * *$ & -2.83 & $-5.29 * * *$ & -1.98 & $-3.82 * * *$ & -1.25 & $-4.11 * * *$ & -1.48 & $-4.53 * * *$ \\
\hline irsr & -2.55 & $-6.81 * * *$ & -3.35 & $-7.34 * * *$ & -1.42 & $-6.15 * * *$ & $-3.83 * * *$ & $-7.39 * * *$ & -1.68 & $-7.03 * * *$ \\
\hline
\end{tabular}

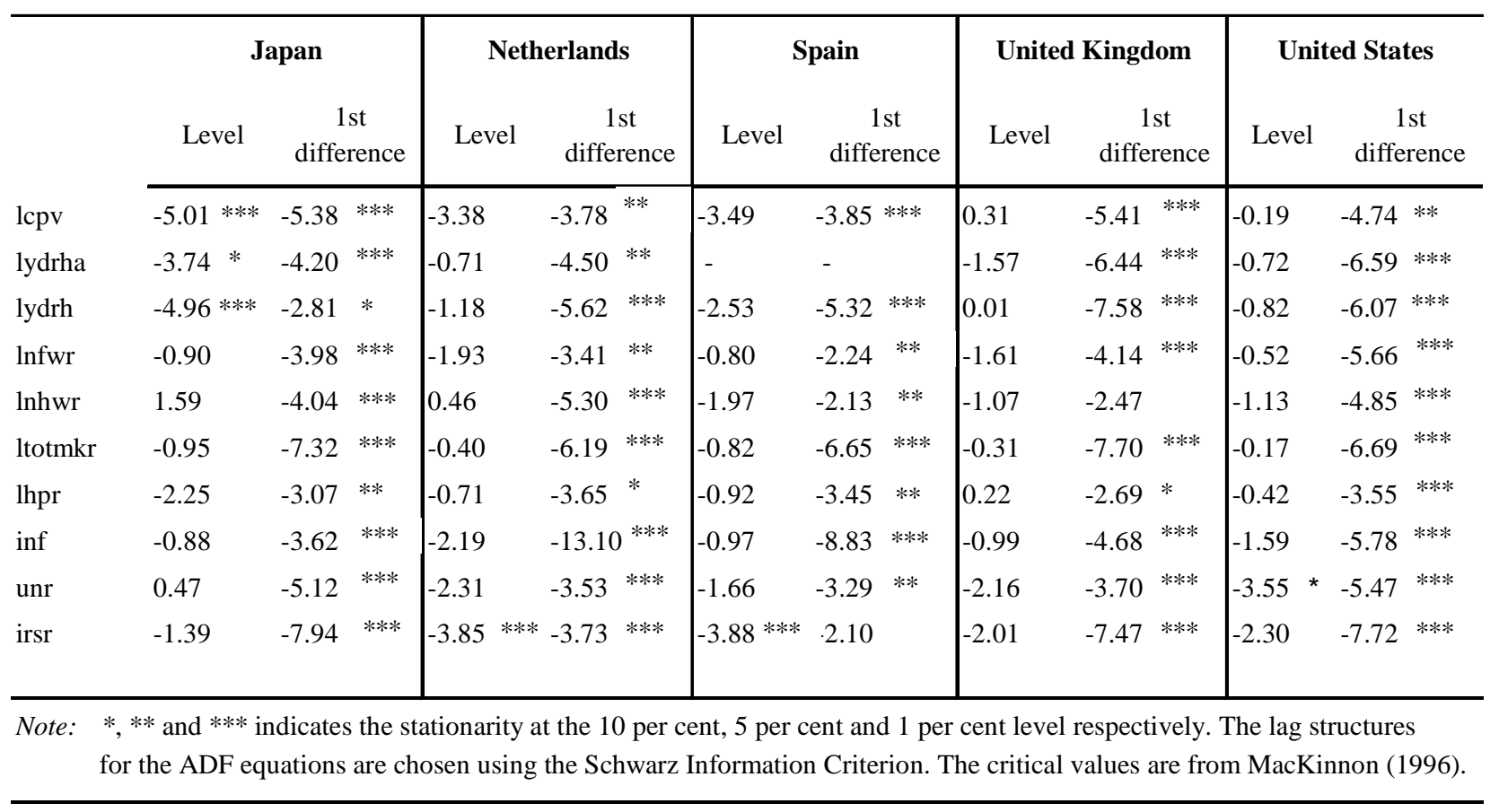




\section{ANNEX II - DATA DESCRIPTION}

52. Housing wealth and financial wealth series were used for Australia, Canada, France, Japan, the Netherlands, Spain, the United Kingdom and the United States. House price indices and stock market capitalisation data were used to proxy the wealth variables for Germany and Italy. In these two countries, the calculation of the marginal propensity to consume out of wealth was done using the short samples of wealth data available. Housing wealth and financial wealth are amounts outstanding at the end of the period. Annual wealth data have been interpolated to semi-annual frequency using a cubic interpolation method with the last observation matching to the source data. The household sector includes non-profit institutions serving households.

\section{Real net housing wealth}

53. In Australia, annual housing assets data are defined as non-financial wealth (including durable goods). In Canada, housing wealth series are defined as residential structures and are available on a quarterly basis. In France, annual data for housing wealth are defined as "actifs immobiliers". In Germany, annual data for housing wealth are defined as dwellings. In Italy, annual series are defined as "abitazioni". In Japan, annual data for housing wealth are defined as fixed assets and land ( 75 per cent of the value of land owned by households is included in the housing asset variable). In the Netherlands, annual data for housing wealth are defined as owner occupied homes. In Spain, annual data for housing wealth are defined as "inmobiliario total". In the United Kingdom, annual data for housing assets are defined as residential buildings. Housing assets are defined as real estate in the United States and are available on a quarterly basis. For all countries, housing assets are expressed at market value. Net housing wealth series are constructed as housing assets minus home mortgages. The private consumption deflator from the OECD Analytical database is used to calculate the real net housing wealth variable.

\section{Real net financial wealth}

54. Financial assets comprise currency and deposits, securities other than shares, loans, shares and other equity, insurance technical reserves and other accounts receivable/payable. Not included are assets with regard to social security pension insurance schemes. In Canada, the United Kingdom and the United States, data were available on a quarterly basis. For the other countries, data were available on an annual basis. Net financial assets are constructed as financial assets minus financial liabilities excluding mortgages. For all countries, net financial assets are expressed at market value. The private consumption deflator from the OECD Analytical database is used to calculate the real net financial wealth variable.

\section{Real net labour income}

55. Labour income is defined as after-tax labour income and transfer income. Income from selfemployed and property income have been excluded from the definition of labour income because they include (partially for the self-employed) the return earned on financial wealth. 


\section{Real house prices}

56. Quarterly and/or annual data on real property prices have been provided by the Bank of International Settlements and are based on national sources. These data are not strictly comparable across countries due of differences in definitions. In a majority of countries, the house price index covers house prices on a national basis. However, in Australia, the index refers to a weighted average of capital cities and regional areas, whereas in Germany, the index refers to the price of houses located in Western Germany. In Japan, the price index refers to residential land prices. Furthermore, in some countries the index related to prices of existing and/or new housing, to prices of houses for owner-occupation only or also to prices of second residences, to prices of housing for which a loan has been applied for only or is a mix-adjusted house price index taking into account several differences in property type.

\section{Real stock market capitalisation}

57. The total market capitalisation series were extracted from Datastream on a daily basis for each half year (i.e. 30 June and 31 December). The private consumption deflator from the OECD Analytical database is used to calculate the real stock market capitalisation variable.

\section{Sources}

58. The sources for the wealth data and the mortgage series are the following: For the United States, Federal Reserve Statistical Release, Flow of Funds Accounts of the United States, September 2003. For Japan, Economic Planning Agency, Government of Japan, Annual Report on National Accounts, 1998 and 2003. For Germany, Deutsche Bundesbank, Monthly Report and Financial accounts 1991-2002. For France, INSEE, Comptes Nationaux, Rapport sur les comptes de la Nation 2002, Comptes financiers 19952002 and unpublished data from Bank of France. For Italy, unpublished data from Banca d'Italia and Supplements to the Statistical Bulletin. For the United Kingdom, Office for National Statistics and National Accounts and Financial Statistics. For Canada, Bank of Canada unpublished series. For Australia, the series are from the data appendix of Tan and Voss (2002). For the Netherlands, the Central Planning Bureau, unpublished series. For Spain, Bank of Spain Financial accounts and Estudios de la Fundacion de las Cajas de Ahorros Confederadas, 1984-2000.

59. Other data come from the OECD Analytical Database (ADB). The frequency is semi-annual. Samples vary with data availability, but are generally between 1975 and 2002. 


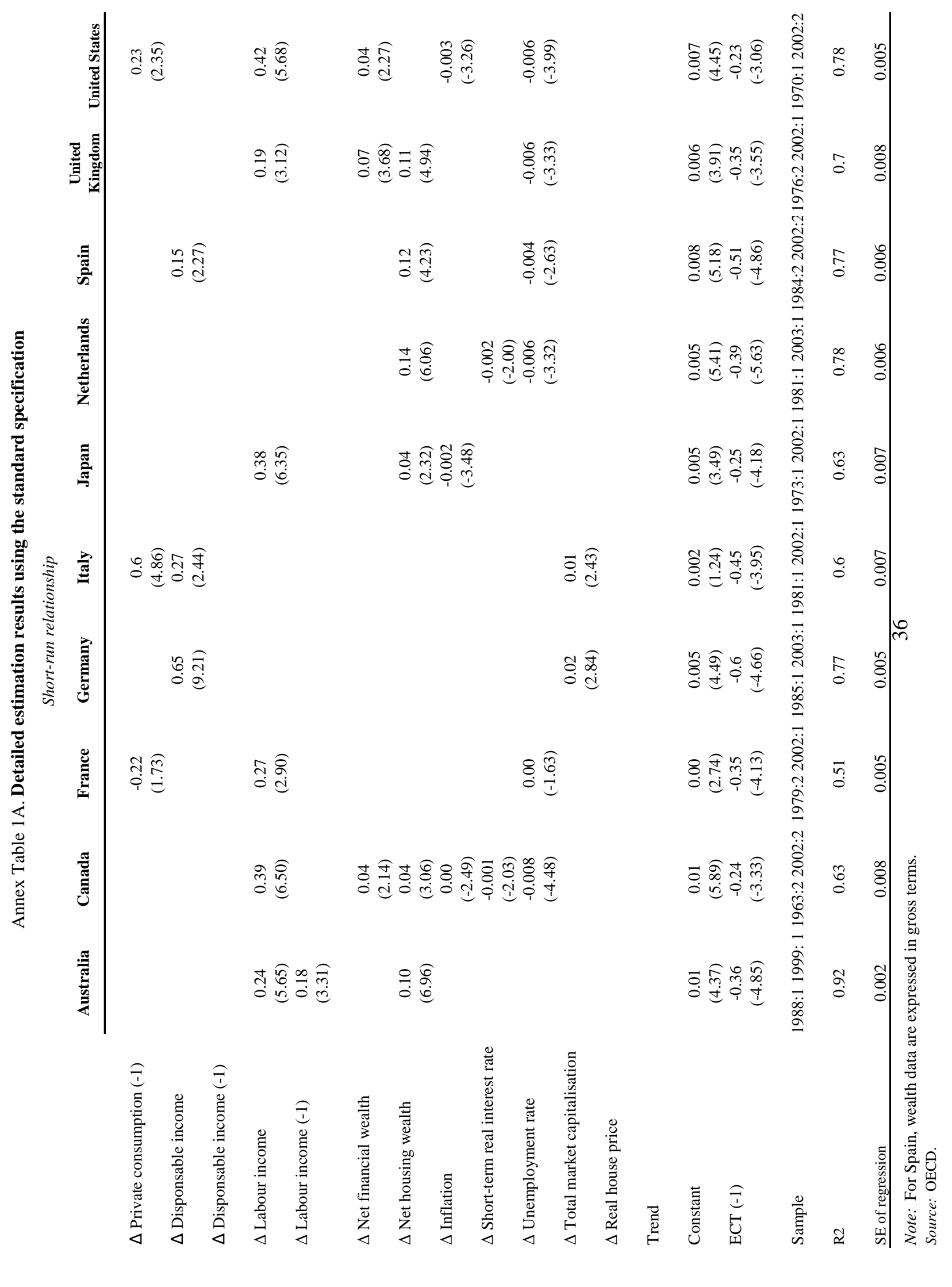




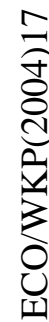

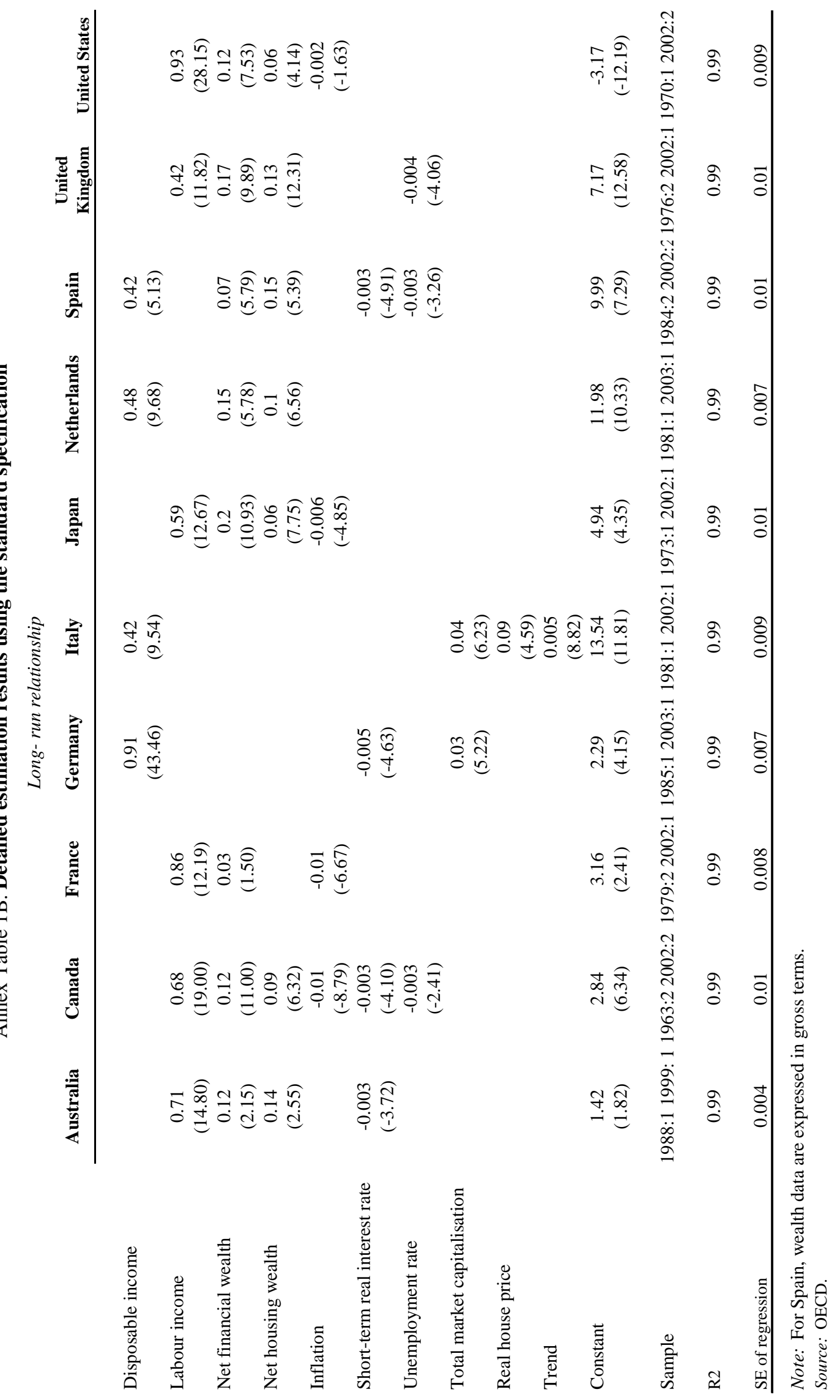

nิ 


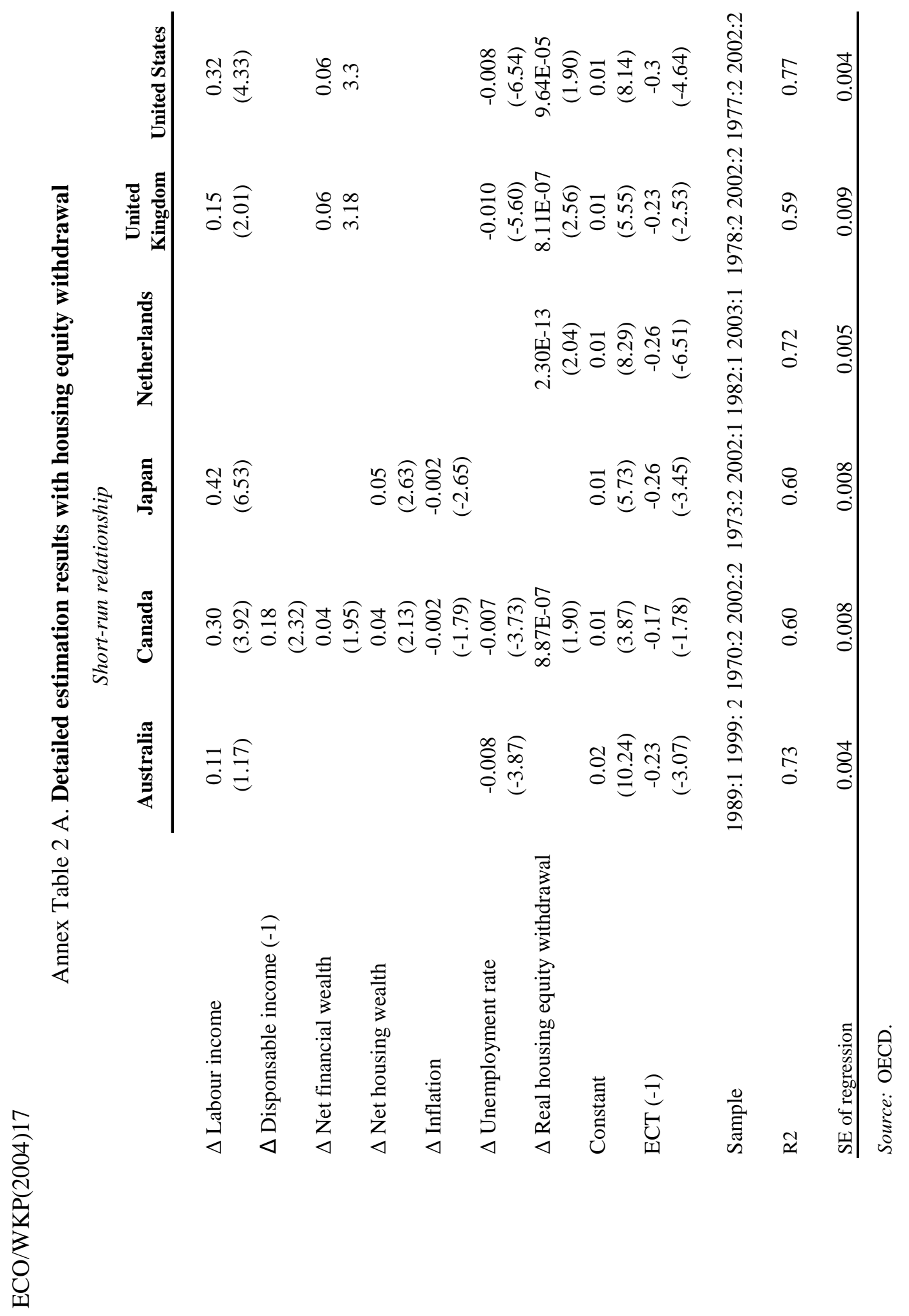

$\infty$ 


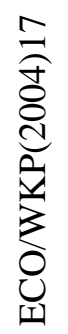

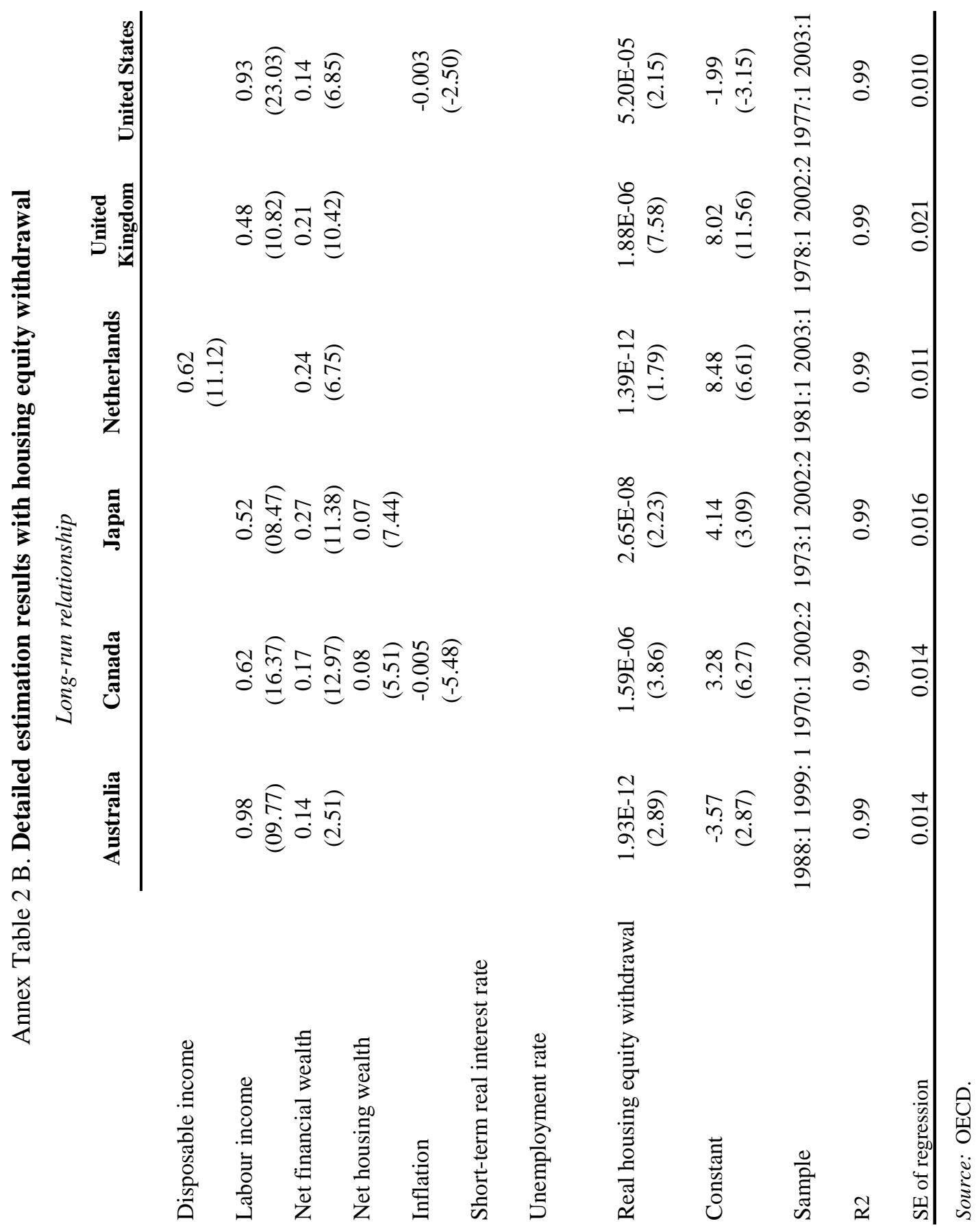

ले 
Annex Table 3. Regulatory limitations on LTV ratios

\begin{tabular}{|c|c|c|c|c|}
\hline & $\begin{array}{c}\text { Property valuation } \\
\text { method }\end{array}$ & $\begin{array}{c}\text { Restrictions } \\
\text { on valuation } \\
\text { method }\end{array}$ & $\begin{array}{c}\text { Regulatory limits on } \\
\text { LTV }\end{array}$ & Link with capital adequacy \\
\hline Australia & OMV & $\mathrm{Y}$ & $\begin{array}{l}80 \%(100 \% \text { if } \\
\text { insured })\end{array}$ & $\begin{array}{l}50 \% \text { weight, subject to } \\
\text { insurance if loan is above } \\
80 \% \text { limit }\end{array}$ \\
\hline Belgium & OMV / MLV & $\mathrm{N}$ & None & $\begin{array}{l}50 \% \text { weight, subject to } \\
\text { prudent valuation of collateral }\end{array}$ \\
\hline Canada & OMV (or variant) & $\mathrm{N}$ & $75 \%$ (95\% if insured) & $\begin{array}{l}50 \% \text { weight if loan is up to } \\
75 \% \text { limit; } 0 \% \text { weight if } \\
\text { CMHC-insured }\end{array}$ \\
\hline Denmark & n.a. & n.a. & $80 \%$ & None \\
\hline Finland & n.a & n.a. & None & None \\
\hline France & OMV & $\mathrm{Y}$ & $\begin{array}{l}60 \% \text { to be eligible for } \\
\text { mortgage-backed } \\
\text { securities }\end{array}$ & None \\
\hline Germany & MLV & Y & $\begin{array}{l}60 \% \text { to be eligible for } \\
\text { mortgage-backed } \\
\text { securities }\end{array}$ & $\begin{array}{l}50 \% \text { weight for first mortgages } \\
\text { if loan is up to } 60 \% \text { limit }\end{array}$ \\
\hline Ireland & OMV & $\mathrm{N}$ & $\begin{array}{l}80 \% \text { (only for } \\
\text { building societies) }\end{array}$ & None \\
\hline Italy & OMV & $\mathrm{N}$ & $\begin{array}{l}80 \%(100 \% \text { if } \\
\text { guaranteed })\end{array}$ & $\begin{array}{l}50 \% \text { weight if loan is up to } \\
80 \% \text { limit }\end{array}$ \\
\hline Japan & n.a. & $\mathrm{N}$ & None & $\begin{array}{l}50 \% \text { weight for first } \\
\text { mortgages }\end{array}$ \\
\hline Netherlands & OMV & $\mathrm{N}$ & None & $\begin{array}{l}50 \% \text { weight for part of the loan } \\
\text { up to } 75 \% \text { of collateral; } 0 \% \\
\text { weight if NHG-insured }\end{array}$ \\
\hline Spain & $\begin{array}{l}\text { Prudent valuation } \\
\text { certified by authorised } \\
\text { appraiser }\end{array}$ & Yes & $\begin{array}{l}80 \% \text { to be eligible for } \\
\text { mortgage-backed } \\
\text { securities }\end{array}$ & $\begin{array}{l}50 \% \text { weight, subject to } \\
\text { prudent valuation of collateral }\end{array}$ \\
\hline Sweden & OMV & No & None & $\begin{array}{l}50 \% \text { weight if loan is up to } \\
100 \% \text { of collateral }\end{array}$ \\
\hline Switzerland & $\begin{array}{l}\text { Mortgage lending } \\
\text { value }\end{array}$ & n.a. & None & $\begin{array}{l}50 \% \text { weight up to } 2 / 3 \text { of market } \\
\text { value; } 75 \% \text { weight above that } \\
\text { limit }\end{array}$ \\
\hline $\begin{array}{l}\text { United } \\
\text { Kingdom }\end{array}$ & OMV & No & $\begin{array}{l}100 \% \text { (only for } \\
\text { building societies) }\end{array}$ & $\begin{array}{l}50 \% \text { weight if loan is up to } \\
90 \% \text { of collateral; } 60 \% \text { weight } \\
\text { above that limit }\end{array}$ \\
\hline United States & OMV & $\begin{array}{l}\text { No (but } \\
\text { appraisers } \\
\text { need to be } \\
\text { certified) }\end{array}$ & $90 \%$ if not guaranteed & $\begin{array}{l}50 \% \text { weight if loan is up to } \\
90 \% \text { of collateral; } 100 \% \text { weight } \\
\text { above that limit }\end{array}$ \\
\hline
\end{tabular}

OMV = open market value; MLV = Mortgage lending value. The MLV must be based on a prudent assessment of the market value (in Germany the typical adjustment factor is 20/25 per cent).

Source: Contact Group (2002), ECB (2003). 
Annex Table 4. Taxation of residential property

\begin{tabular}{|c|c|c|c|c|c|c|}
\hline & $\begin{array}{c}\text { Imputed } \\
\text { rental income } \\
\text { taxed }\end{array}$ & $\begin{array}{l}\text { Tax relief on n } \\
\text { interest }\end{array}$ & $\begin{array}{l}\text { ortgages } \\
\text { principal } \\
\text { repayments }\end{array}$ & $\begin{array}{c}\text { Capital gains on } \\
\text { housing assets } \\
\text { taxable }\end{array}$ & Inheritance tax & Stamp duty \\
\hline Austria & $\mathrm{N}$ & $\begin{array}{c}\mathrm{Y} \\
\text { (up to ceiling) }\end{array}$ & $\mathrm{N}$ & $\begin{array}{c}\mathrm{Y} \\
\text { (if sold }<10 \text { years) }\end{array}$ & $\mathrm{Y}$ & $6 \%$ \\
\hline Belgium & $\begin{array}{c}\mathrm{Y} \\
\text { (with fixed } \\
\text { deduction) }\end{array}$ & $\begin{array}{c}\text { Y } \\
\text { (up to imputed } \\
\text { rental income) }\end{array}$ & $\begin{array}{c}\mathrm{Y} \\
\text { (within } \\
\text { limit) }\end{array}$ & $\begin{array}{c}\mathrm{Y} \\
\text { (if sold }<5 \text { years) } \\
\text { POOD are exempt }\end{array}$ & $\mathrm{Y}$ & $\begin{array}{c}10 \%-12.5 \% \\
\text { (5\%-6\% for modest } \\
\text { houses) }\end{array}$ \\
\hline Canada & $\mathrm{N}$ & $\mathrm{N}$ & $\mathrm{N}$ & $\begin{array}{c}\text { Y } \\
\text { (on 50\% of gains) } \\
\text { POOD are exempt }\end{array}$ & $\begin{array}{c}\mathrm{N} \\
\text { (but subject to } \\
\text { capital gains tax) }\end{array}$ & n.a \\
\hline Denmark & $\mathrm{Y}$ & $\mathrm{Y}$ & n.a. & $\begin{array}{c}\text { Y } \\
\text { POOD are exempt }\end{array}$ & $\mathrm{Y}$ & $\begin{array}{c}1.5 \% \\
\text { total trading costs } 7.2 \%\end{array}$ \\
\hline Germany & $\mathrm{N}$ & $\mathrm{N}$ & $\mathrm{N}$ & $\begin{array}{c}\mathrm{Y} \\
\text { (if sold }<10 \text { years) } \\
\text { POOD are exempt }\end{array}$ & $\begin{array}{c}\mathrm{Y} \\
\text { (lower than for } \\
\text { financial assets) }\end{array}$ & $3.5 \%$ \\
\hline Greece & $\begin{array}{c}\mathrm{Y} \\
\text { (for POOD) }\end{array}$ & $\begin{array}{c}\mathrm{Y} \\
\text { (for POOD) }\end{array}$ & n.a. & $\mathrm{N}$ & $\mathrm{Y}$ & $11 \%-13 \%$ \\
\hline Finland & $\mathrm{N}$ & $\begin{array}{c}\mathrm{Y} \\
\text { (up to a ceiling) }\end{array}$ & n.a. & $\begin{array}{c}\text { Y } \\
\text { POOD exempt if } \\
\text { sold }>2 \text { years }\end{array}$ & $\mathrm{Y}$ & $\begin{array}{c}4 \% \\
\text { (first-time buyers } \\
\text { exempt) }\end{array}$ \\
\hline France & $\mathrm{N}$ & $\mathrm{N}$ & $\mathrm{N}$ & $\begin{array}{c}\mathrm{Y} \\
\text { POOD are exempt }\end{array}$ & $\mathrm{Y}$ & $2 \%-3 \%$ \\
\hline Ireland & $\mathrm{N}$ & Y & $\mathrm{N}$ & $\begin{array}{c}\text { Y } \\
\text { POOD are exempt }\end{array}$ & $\mathrm{Y}$ & $0 \%-9 \%$ \\
\hline Italy & $\begin{array}{c}\mathrm{N} \\
\text { (for POOD) }\end{array}$ & $\begin{array}{c}\mathrm{Y} \\
\text { (for POOD) }\end{array}$ & $\mathrm{N}$ & $\begin{array}{c}\mathrm{Y} \\
(50 \% \text { for POOD) }\end{array}$ & Y (until 2001) & $\begin{array}{c}10 \% \\
(3 \% \text { for POOD) }\end{array}$ \\
\hline Luxembourg & $\mathrm{Y}$ & Y & n.a. & $\begin{array}{c}\mathrm{Y} \\
\text { POOD are exempt }\end{array}$ & $\mathrm{Y}$ & $7 \%-10 \%$ \\
\hline Netherlands & $\mathrm{Y}$ & Y & $\mathrm{N}$ & $\mathrm{N}$ & $\begin{array}{c}\mathrm{Y} \\
\text { (above tax free } \\
\text { threshold) }\end{array}$ & $6 \%$ \\
\hline Norway & Y & $\begin{array}{c}\text { Partly } \\
\text { (as other interest } \\
\text { expenses) }\end{array}$ & $\mathrm{N}$ & $\mathrm{Y}$ & $\mathrm{Y}$ & n.a. \\
\hline Portugal & $\mathrm{N}$ & $\mathrm{Y}$ & n.a. & $\begin{array}{c}\mathrm{Y} \\
\text { (exempt if reinvested } \\
\text { in }<2 \text { years) }\end{array}$ & Y & $0.8 \%$ \\
\hline Spain & $\begin{array}{c}\mathrm{N} \\
\text { (for POOD) }\end{array}$ & Y & $\mathrm{Y}$ & $\begin{array}{c}\mathrm{Y} \\
\text { (exempt if reinvested) }\end{array}$ & $\mathrm{Y}$ & n.a. \\
\hline Sweden & $\mathrm{Y}$ & Y & $\mathrm{N}$ & $\mathrm{Y}$ & $\mathrm{Y}$ & $1.5 \%-3 \%$ \\
\hline Switzerland & $\mathrm{Y}$ & $\begin{array}{c}\mathrm{Y} \\
\text { (up to total } \\
\text { property income } \\
\text { + fixed amount) }\end{array}$ & $\mathrm{N}$ & $\begin{array}{c}\text { Y } \\
\text { (cantonal only) } \\
\text { POOD are exempt }\end{array}$ & $\begin{array}{c}\mathrm{Y} \\
\text { (cantonal only) }\end{array}$ & n.a. \\
\hline $\begin{array}{l}\text { United } \\
\text { Kingdom }\end{array}$ & $\mathrm{N}$ & $\mathrm{N}$ & $\mathrm{N}$ & $\begin{array}{c}\text { Y } \\
\text { POOD are exempt }\end{array}$ & Y & $\begin{array}{c}1 \%, 2 \% \text { or } 4 \% \\
\text { (depends on house value) }\end{array}$ \\
\hline United States & $\mathrm{N}$ & $\begin{array}{c}\mathrm{Y} \\
\text { (up to ceiling) }\end{array}$ & $\mathrm{N}$ & $\begin{array}{l}\text { Y (until 2002) } \\
\text { (deduction for POOD } \\
\text { if held >2 years) }\end{array}$ & $\begin{array}{c}\mathrm{Y} \\
\text { (to be phased out) }\end{array}$ & n.a \\
\hline
\end{tabular}




\section{BIBLIOGRAPHY}

AOKI, K., J. PROUDMAN and G. VLIEGHE (2002), "Houses as Collateral: Has the Link between House Prices and Consumption in the U.K. Changed?", Federal Reserve Bank of New York Economic Policy Review, Vol.8, no.1, New York, May.

BARKER, K. (2003), Review of Housing Supply, Interim Report, HM Treasury, December.

BENJAMIN, J.D., P. CHINLOY and G.D. JUD (2003),

"Real estate versus financial wealth in consumption", Journal of Real Estate Finance and Economics, Forthcoming.

BOONE, L. and N. GIROUARD (2002),

"The stock market, the housing market and consumer behaviour", OECD Economic Studies, No. 35, Paris.

BORIO, C. and P. MCGUIRE (2004), “Twin peaks in equity and housing prices?”, BIS Quarterly Review, March.

BRAMLEY, G. (1993), "The impact of land use planning and tax subsidies on the supply and price of housing in Britain", Urban Studies, Vol. 30, No. 1.

BYRNE, J and E.P. DAVIS (2003), "Disaggregate wealth and aggregate consumption: an investigation of empirical relationship for the G7", NIESR Working Paper, London.

CASE, E., J. QUIGLEY and R. SHILLER (2001), "Comparing wealth effects: the stock market versus the housing market", NBER Working Paper No. 8606.

CASE, K.E. and R.J. SHILLER (2003), "Is there a bubble in the housing market?", Brooking Papers on Economic Activity, 2:2003.

CHO, M. (1996), "House price dynamics: a survey of theoretical and empirical issues", Journal of Housing Research, Vol. 7, Issue 2.

CONTACT GROUP ON ASSET PRICES (2002), "Turbulence in asset markets: the role of micro policies", Bank for International Settlements, Basle, September.

DE BONDT, G, B. MOJON and N. VALLA (2003), "Term structure and the sluggishness of retail bank rates in the euro area", European Central Bank, mimeo, April.

DEUTSCHE BUNDESBANK (2003), "Macroeconomic aspects of share price developments", Monthly Report, March.

DI, Z.X. (2003), "Housing wealth and household net wealth in the United States: a new profile based on the recently released 2001 SCF data", Joint Center for Housing Studies, Harvard University. 
DIAMOND, D.B. and M.J. LEA (1992), "Housing finance in developed countries: an international comparison of efficiency", Journal of Housing Research, Vol. 3, Fannie Mae, Washington.

DROLET, M., R. MORISETTE and X. ZHANG (2002), "The evolution of wealth inequality in Canada, 1984-1999”, Statistics Canada, Analytical Studies Branch Research Paper Series, No. 187.

DVORNAK, N. and M. KOHLER (2003), "Housing wealth, stock market wealth and consumption: a panel analysis for Australia", Reserve Bank of Australia, Research Discussion Paper, No. 07, July.

EUROPEAN CENTRAL BANK (2003), "Structural Factors in the EU Housing Markets”, March.

EUROPEAN MORTGAGE FEDERATION (2002), "Efficiency of mortgage collateral in the European Union”, Comparative Study, European Survey, Brussels.

INTERNATIONAL BUREAU OF FISCAL DOCUMENTATION (IBFD) (2002), European Tax Handbook, 13th annual edition, Amsterdam.

LE MAIRE, G. (2004), “Les effets de richesse et l'arbritage consommation épargne des ménages en France », Claude Fourgeaud Seminar, Direction de la Prévision, Ministère de l'Economie, des Finances et de l'Industrie, January, Paris.

LETTAU, M. and S. LUDVIGSON (2003),

"Understanding trend and cycle in asset values: reevaluating the wealth effect on consumption", NBER Working Paper, No. 9848, Cambridge, July.

LUDWIG, A. and T. SLOK (2004), "The relationship between stock prices, house prices and consumption in OECD countries", Topics in Macroeconomics, Volume 4, Issue 1.

MACLENNAN, D., J. MUELLBAUER and M. STEPHENS (1999), “Asymmetries in housing and financial market institutions and EMU”, CEPR Discussion Paper, No. 2062, January.

McCARTHY, J. and R.W. PEACH (2002), "Monetary Policy Transmission to Residential Investment" Federal Reserve Bank of New York Economic Policy Review, Vol.8, no.1, New York, May.

MERCER OLIVER WYMAN (2003), Study on the Financial Integration of European Mortgage Markets, European Mortgage Federation, Brussels, October.

MITCHELL, O.S. and J. PIGGOTT (2004),“Unlocking housing equity in Japan”, NBER Working paper, No. 10340, Cambridge, March.

MUELLBAUER, J. and A. MURPHY (1997), "Booms and busts in the UK housing market", The Economic Journal, Vol. 107, No 775, November.

NOGUCHI, Y. and J.M. POTERBA (1994), "Housing markets in the United States and Japan", National Bureau of Economic Research Conference Report, University of Chicago Press, Chicago and London.

OECD (1999), OECD Economic Survey of Denmark, Paris.

OECD (2003a), OECD Economic Survey of Spain, Paris.

OECD (2003b) OECD Economic Survey of Luxembourg, Paris. 
ECO/WKP(2004)17

OECD (2003), Economic Survey of the United Kingdom, Paris.

OECD (2004a), OECD Economic Survey of United Kingdom, Paris.

OECD (2004b), OECD Economic Survey of the Netherlands, Paris.

PICHETTE, L. and D. TREMBLAY (2003), “Are wealth effects important for Canada”, Bank of Canada Working Paper, No. 30, Ottawa, October.

STOCK, J.H. and M. WATSON (1993), “A simple estimator of cointegrating vectors in higher order integrated systems", Econometrica, Vol. 61, No. 4.

STOCK, J.H. and M. WATSON (2002), "Has the Business Cycle Changed and Why?", NBER Working Paper No. 9127, Cambridge, September.

SUTTON, G.D. (2002), "Explaining changes in house prices”, BIS Quarterly Review, September.

SWANK, J., J. KAKES and A.F. TIEMAN (2002), “The housing ladder, taxation and borrowing constraints", De Nederlandsche Bank Staff Reports, No 9.

TAN, A and G. VOSS (2003), "Consumption and wealth in Australia", The Economic Record, Vol. 79, No. 244, March.

TSATSARONIS, K. and H. ZHU (2004), "What drives house price dynamics: cross-country evidence", BIS Quarterly Review, March.

US DEPARTMENT OF HOUSING AND URBAN DEVELOPMENT (1996), Providing Alternatives to Mortgage Foreclosure: A Report to Congress, Washington, March.

VAN DEN NOORD, P. (2004), "Tax incentives and house price volatility in the euro area: theory and evidence", Économie Internationale, forthcoming.

VENTI, S.F. and D.A. WISE (2001), “Aging and housing equity”, NBER Working paper, No. 8608, Cambridge, November. 


\section{WORKING PAPERS}

The full series of Economics Department Working Papers can be consulted at www.oecd.org/eco/Working_Papers/

393. Long-term Budgetary Implications of Tax-favoured Retirement Plans (June 2004) Alain de Serres, Pablo Antolin and Christine de la Maisonneuve

392. Enhancing Income Convergence in Central Europe after EU Accession (June 2004) Patrick Lenain and Lukasz Rawdanowicz

391. Asset Price Cycles, “One-Off” Factors and Structural Budget Balances (June 2004) Nathalie Girouard and Robert Price

390. Channels for Narrowing the US Current Account Deficit and Implications for Other Economies (May 2004) Anne-Marie Brook, Franck Sédillot and Patrice Ollivaud

389. Product Market Competition and Economic Performance in Norway (May 2004) Jens Høj and Michael Wise.

388. Product Market Competition and Economic Performance in Sweden (May 2004) Deborah Roseveare, Martin Jørgensen and Lennart Goranson

387. Product Market Competition and Economic Performance in Japan (May 2004) Jens Høj and Michael Wise

386. Migration and Integration of Immigrants in Denmark (May 2004) Deborah Roseveare and Martin Jørgensen

385. Factors Driving Risk Premia (April 2004) Torsten Sløk and Mike Kennedy

384. Rationalising Public Expenditure in the Slovak Republic (March 2004) Rauf Gönenç and Peter Walkenhorst

383. Product Market Competition and Economic Performance in Switzerland (March 2004) Claude Giorno, Miguel Jimenez and Philippe Gugler

383. Concurrence sur les Marchés de Produits et Performance Économique en Suisse (Mars 2004) Claude Giorno, Miguel Jimenez and Philippe Gugler

382. Differences in Resilience between the Euro-Area and US Economies (March 2004) Aaron Drew, Mike Kennedy and Torsten Sløk

381. Product Market Competition and Economic Performance in Hungary (March 2004) Carl Gjersem, Philip Hemmings and Andreas Reindl

380. Enhancing the Effectiveness of Public Spending: Experience in OECD Countries (February 2004) Isabelle Joumard, Per Mathis Kongsrud, Young-Sook Nam and Robert Price

379. Is there a Change in the Trade-Off between Output and Inflation at Low or Stable Inflation Rates? Some Evidence in the Case of Japan

(February 2004) Annabelle Mourougane and Hideyuki Ibaragi

378. Policies bearing on product market competition and growth in Europe (January 2004) Carl Gjersem 


\section{ECO/WKP(2004)17}

377. Reforming the Public Expenditure System in Korea (December 2003) Young-Sook Nam and Randall Jones

376. Female Labour Force Participation: Past Trends and Main Determinants in OECD Countries (December 2003) Florence Jaumotte

375. Fiscal Relations Across Government Levels (December 2003) Isabelle Joumard and Per Mathis Kongsrud

374. Health-Care Systems: Lessons from the Reform Experience (December 2003) Elizabeth Docteur and Howard Oxley

373. Non-Tariff Measures Affecting EU Exports: Evidence from a Complaints-Inventory (December 2003) Peter Walkenhorst and Barbara Fliess

372. The OECD Medium-Term Reference Scenario: Economic Outlook No. 74 (November 2003) Peter Downes, Aaron Drew and Patrice Ollivaud

371. Coping with Ageing: A Dynamic Approach to Quantify the Impact of Alternative Policy Options on Future Labour Supply in OECD Countries

(November 2003) Jean-Marc Burniaux, Romain Duval and Florence Jaumotte

370. The Retirement Effects of Old-Age Pension and Early Retirement Schemes in OECD Countries (November 2003) Romain Duval

369. Policies for an Ageing Society: Recent Measures and Areas for Further Reform (November 2003) Bernard Casey, Howard Oxley, Edward Whitehouse, Pablo Antolin, Romain Duval, Willi Leibfritz

368. Financial Market Integration in the Euro Area (October 2003) Carl Gjersem

367. Recent and Prospective Trends in Real Long-Term Interest Rates: Fiscal Policy and Other Drivers (September 2003) Anne-Marie Brook

366. Consolidating Germany's finances: Issues in public sector spending reform (September 2003) Eckhard Wurzel

365. Corporate Taxation of Foreign Direct Investment Income 1991-2001 (August 20030) Kwang-Yeol Yoo

364. Indicator Models of Real GDP Growth in Selected OECD Countries (July 2003) Franck Sédillot and Nigel Pain

363. Post-Crisis Change in Banking and Corporate Landscapes - the Case of Thailand (July 2003) Margit Molnar

362. Post-Crisis Changes in Banking and Corporate Landscapes in Dynamic Asia (June 2003) Margit Molnar

361. After The Telecommunications Bubble (June 2003) by Patrick Lenain and Sam Paltridge

360. Controlling Public Spending in Iceland (June 2003) Hannes Suppanz

359. Policies and International Integration: Influences on Trade and Foreign Direct Investment (June 2003) Giuseppe Nicoletti, Steve Golub, Dana Hajkova, Daniel Mirza, Kwang-Yeol Yoo 